\title{
Fekete István és Cséplö József levelezése (forrásközlés)
}

\author{
LANSZKINÉ SZÉLES GABRIELLA
}

Kaposvári Egyetem Agrár- és Környezettudományi Kar, H-7401 Kaposvár, Pf. 16., e-mail: lanszkine.gabriella@ke.hu \begin{abstract}
„A magyar irodalomhoz való viszonya alapján kétféle ember létezik. Az egyik imádja Fekete Istvánt, a másik nem
\end{abstract} ismeri."

LANSZKINÉ SzÉLES, G.: Correspondence of István Fekete and József Cséplő.

Abstract: Publication of the correspondence of István Fekete and József Cséplö is thanked to the children of József Cséplő. Since József Cséplő was 19 years younger than István Fekete, the writer welcomed the advice of his great idol. In addition, the strong connection was rooted in their same place of origin; the distance between villages Gölle and Fonó is only $7 \mathrm{~km}$. Their letters and postcards survived for the posterity.

Keywords: letters of István Fekete, Gölle, Fonó, Somogy county

„- István, címeres akasztófavirág voltál, és az is maradsz! Ebben a megállapításban csak a címeradományozásnak örültem, mert eddig nem volt címerem, s ezt nagyon nélkülöztem. Ezek a régi címek is tetszettek nekem, de nem annyira, mint ez az új, amelyet ismeretlen apától kaptam, aki a kerítésünk mellett ment kisfiával, és ablakomra mutatott. - Látod kisfiam, itt jó ember lakik. Olyan meggyőződéssel mondta, hogy elhittem, s azóta érzem is, hogy jó ember vagyok."1 Fekete István az előző sorokban a rá jellemző humorral, természetesen az előzmények ismeretében nyilvánítja ki és adresszálja magára a jó ember címkéjét.

„Öregapád jó ember volt!" - ezt mondta Cséplő József is - mint az elöbbi történetben megnyilatkozó egykori apa - csak éppen rám nézve a 2000-es évek elején. Ez az a mondat, aminek köszönhetően Jóska bácsit felkerestem Fonóban, a Somogy megyei kis faluban, ahol mi is lakunk. Csupán csak nagyapám felől szerettem volna érdeklődni tőle, tekintve, hogy én nem ismerhettem, mert a II. világháborút követően a fogságból hazatérve egy héten belül elhunyt. Cséplő József megelégedésemre már az első találkozásunk alkalmával is sokat mesélt, amiböl összességében azt a következtetést vontam le, hogy Ő is: „Jó ember!”2 Különösen azok a történetek ragadtak magukkal, ame-

1 Valló L. 1986:174.

2 Bodó Imre agrármérnök a dombóvári Fekete István Múzeum alapítója, aki szintén Gölle szülötte. Ö már hatéves korában levelet írt Fekete Istvánnak, amire válaszolt is. Bodó Imre Jó Ember Díjat kapott. Ezt a díjat olyan személyek kapják, „akik a szívükkel látva egyszerüen csak teszik a dolgukat önzetlenül, és közben észre sem veszik, hogy milyen sok ember javát szolgálják a széleskörüen értelmezett kultúra területén." lyek arról szóltak, hogyan segített haza sok somogyi katonát a fogságból. Mivel tudott oroszul, ezért egy szovjet doktornő mellett tolmácskodott, így módjában állt kicsit befolyásolni őt a döntéseiben, hogy kit is lehetne mielőbb hazabocsájtani. A hazatért katonák és családtagjaik pedig jöttek hálálkodni Fonóba - a nekik nyújtott segítségért. A Cséplő család ezzel szemben még várhatott egy jó darabig, míg végre maga Cséplő József is hazaérkezett a hadifogságból.

\section{Cséplő József és Fekete István közös gyökerei}

A katonatársakhoz éppúgy kötötte Cséplő Józsefet a földiség, mint Fekete Istvánhoz. Bizony ezek a szálak még ma is erősen füzik össze az egyazon vidékről származó embereket. Valószínű, hogy Fekete István író (1900-1970) (1. ábra) számára a Cséplő Józseffel (1920-2012) (2. ábra) folytatott levelezés során, kezdetben a somogyi kötődésnek lehetett fontos szerepe. Gölle és Fonó között csupán egyetlen falu Kisgyalán (ahogy erre felé mondják, csak „Gyalán”) található, köztük a távolság mindössze $7 \mathrm{~km}$. Gyaláni gyerekként és göllei kisiskolásként, na meg a 'Ballagó idő'-t olvasva számomra is jóleső érzés volt, miszerint Fekete Árpád - Fekete István édesapja - számon tartotta a gyalániakat, mondván például hogy: „Ezek a gyalániak sem jönnek má!" Ugyanis Kaposváron - 1910-ben a Gölléből való beköltözködésük után - Fekete István családja igen közel lakott a piachoz, így ott újra találkozhatott a rég nem látott környékbeli emberekkel.

„Az utolsó képet, az utolsó emléket édesapjáról Fekete Edit így idézi: Egy délutáni sétánkon a gyors sodrású havasi folyó, az Aache partján kérdeztem: Ugye szép? Szép - mondta elgondolkodón - de te nem láttad a Kapost..."3 A somogyi tájhoz, folyóhoz, emberekhez való kötődéséről ez a mondat mindent elárul, ugyanúgy, mint Cséplő Józsefhez írt feltehetőleg első levele.

Fekete István az író - „Hazai olvasóitól köszönö- és üdvözlö levelek százait kapja egy-egy jelesebb ünnep után vagy új könyvek megjelenésekor. (...) A levelek írói mindenféle rendü és rangú emberek. Kisdiákok, kisdobosok és úttörők éppúgy tollat fognak, mint a háziasszonyok, nyugdíjas nagymamák és nagypapák,

3 Valló L. 1986: 180 


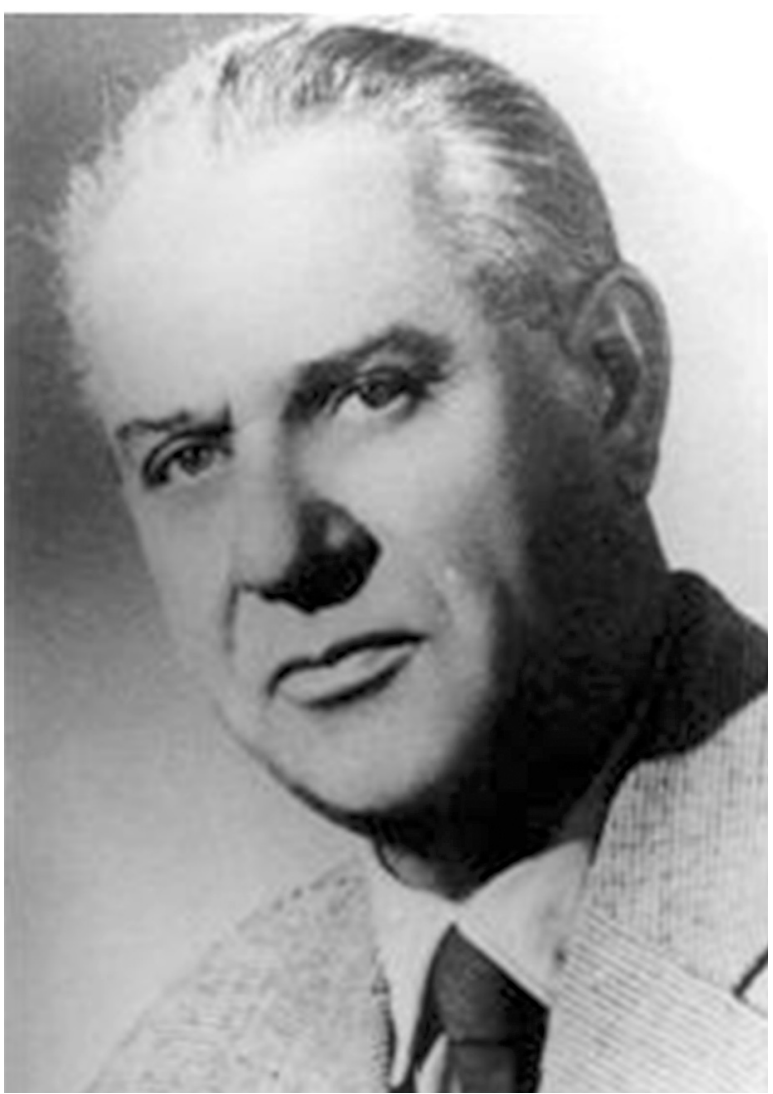

1. ábra. Fekete István

(forrás: http://www.fekete-bp10.sulinet.hu/)

orvosok, mérnökök, papok, tanárok, egyetemista diákok, vagy szakmunkások, termelöszövetkezeti tagok és mesteremberek." ${ }^{4}$ Cséplő József is hasonló indíttatásból írta a következőket: „tiszteletből és szeretetből fakadó közeledésnek, (...) a bensőségesebb hangján szólítsam meg."

Fekete István és Cséplő József 1963 és 1970 között folytatott levelezéséhez Cséplő József hagyatékából jutottam, ami gyermekeinek - lányának és fiának - engedélyével kerülhet most közlésre. Cséplő József Fekete Istvánnak szánt levelei legtöbbjét előzőleg letisztázta, így szerencsés módon az elküldött levelek közül is számos a Cséplő hagyatékban fennmaradt. Annak okán, hogy ezek, feltehetően, nem pontosan azonosak az elküldött változattal, ezért nem teljes terjedelemben adom közre azokat.

Fekete Istvánnal nem túl gyakran, de haláláig rendszeresen levelezett Zsoldos György (1901-1955), aki a debreceni főiskolán volt az író egyik legjobb barátja, és aki nem mellékesen egy ideig Kaposváron is élt. Sánta Gábor a személyével kapcsolatban azt írja, hogy „fennmaradt levelezésük a kutatások egyik megkerülhetetlen forrása." ${ }^{5}$ Úgy gondolom, hogy a magyar prózában a „Kétkezi emberek és a természet világá-

4 Valló L. 1986: 165.

5 Sánta G. 2014: 82.

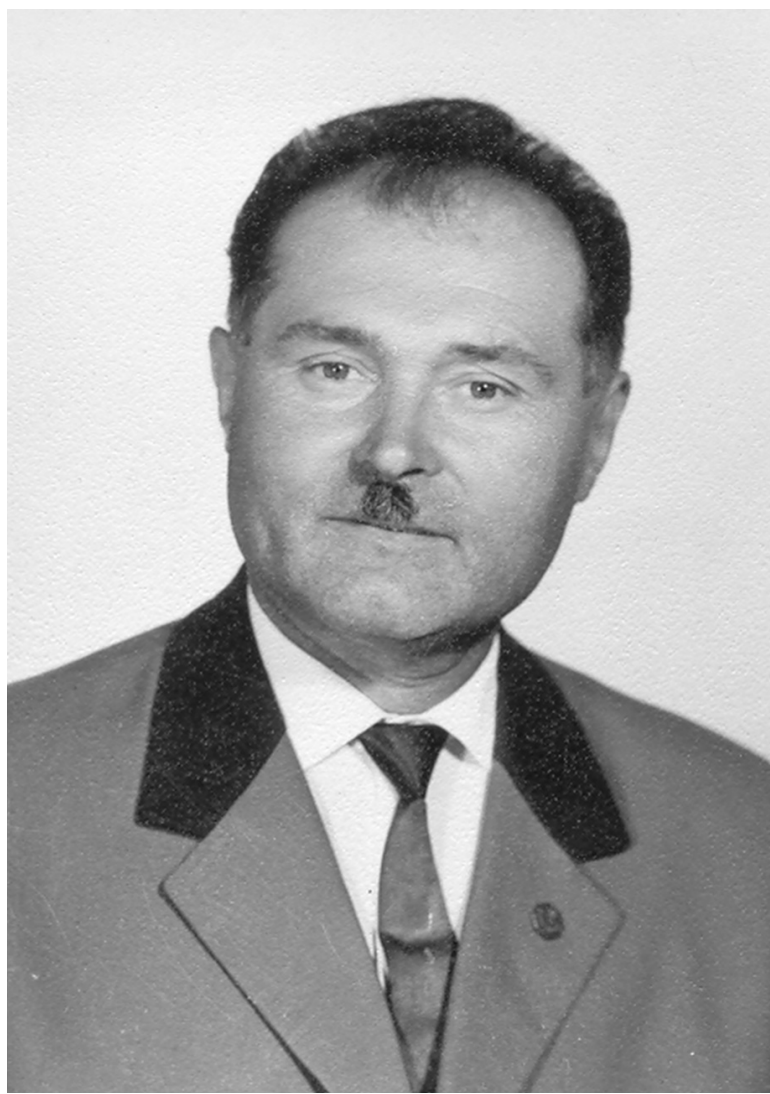

2. ábra. Cséplő József

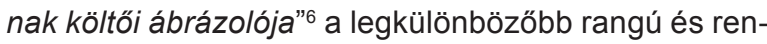
dű emberrel levelezett, és ezeknek a sokszor barátságig szövődött kapcsolatoknak a még fel nem dolgozott írásos emlékei jelentős mértékben járulhatnak hozzá az íróról alkotott kép még teljesebbé tételéhez. Cséplő Józseffel, a földivel, a gazdásszal, az írótárssal folytatott levelezését ennek szellemében kezdtem kutatni.

Cséplő József „középparaszti családba született 1920. május 19-én, Fonó községben. Születése óta ott lakott. Alapfokú erdészvizsgát és vadőri képesitést szerzett. A népfőiskolán, Érden végzett, utána szőlészborász lett. Házasságából két gyermek született. Részt vett a II. világháborúban. A háború befejezésével három év hadifogság következett. Hazatérése után 'kulák lett', összesen 1117 nap politikai fogsággal sújtották. „De sem testben, sem lélekben nem tudott megtörni ez a kínkeserves életfejezet."' - írja saját magáról.

„Sok-sok elbeszélésem, novellám került publikálásra a fövárosi és vidéki lapokban. Úgy kezdődött, hogy szántani mentünk nagyapámmal a vízállói dülőbe. Esős idők jártak, de a paraszt egy-egy ilyen licspocsot fel sem vesz, kivárja a végét a pokróc alatt, kabátot kanyarítva magára. Akkor azonban zivatar készülödött. A szél a falu felöl fehér papírt hengergetett felénk. A csikók megrebbentek tőle. A papír szinte rátekeredett a lábomra. Egy Vasárnapi Újság volt. Olvasni

6 Emléktábla Fekete István szülöházán, Göllében 
kezdtem, Fekete István Dülöúton című elbeszélését nyomtatták a fehér lapra. Nagyon tetszett: családunk sorsát, a falu életét véltem kiolvasni belöle. Mire a zivatarfelhő lombot szaggató viharával elvonult, már háromszor olvastam el. Nagyapám is kíváncsi lett, mi van az újságban. Szinte kívülröl mondtam fel neki. $A$ végén megtörölte a szemét, mintha porszemet fújt volna bele a szél. „Na, Pici, na, Madár!” Barázdába állt, szántott tovább. Ez az óra, ez a nap második születésnapom lett. Azóta veszek tollat a kezembe, hogy tovább adjam, ami velem, velünk történt ..." - Vallotta indulásáról Cséplő József.

Évek múltán Fekete István barátságát is magáénak tudhatta, erről a köztük folyó levelezés is tanúbizonyságul szolgál. „Vadászott Izlandon, az Egyesült Államokban, Kanadában, ahol szép zsákmányra tett szert." ${ }^{8}$ A Fekete Istvánnal folytatott levelezését kincsként őrizte a szőlőhegyen. Írói munkásságára a későbbiekben még visszatérek.

\section{Sorsbeli és gondolkodásmódbeli párhuzamok}

Mielőtt a két ízig, vérig somogyi férfiember levélváltásainak tartalmát és hátterét boncolgatnám, személyiségük között néhány érdekes párhuzamra szeretném a figyelmet felhívni, a magyar természetbúvárok, vadászok és vadászírók táborának emblematikus alakja, Fekete István kapcsán. Kiemelendő, hogy ahogy Fekete István, úgy Cséplő József is 'vadász' és nem 'puskás' ember volt. Fekete István „a vadászást ellenben életformaként élte meg: a természetbe a kikapcsolódásért járt, és mert hívő emberként ott érezte magát legközelebb Istenhez."9

Ugyanezt elmondhatjuk Cséplő Józsefről is, mert „Cséplö József valamennyi müvének meghatározója az erdők, mezők világának határtalan szeretete, az ott élö emberek történeteinek megörökítése. Novelláinak, elbeszéléseinek a szőlöhegy és az erdő elemi fontosságú helyszíne, vissza-visszatérő témája a munka és a vadászat."10

„Fekete István, noha maga is sokat vadászott, mégis a természetirodalom lírai vonulatának kiemelkedő képviselője."11 Közös az érdeklődési területük, közös a természetszeretetük, és a vadászat iránti olthatatlan szenvedélyük. A korkülönbség azonban Cséplő József javára szolgál, hisz tizenkilenc évvel volt fiatalabb Fekete Istvánnál, innen a levelekben a Pista bátyám megszólítás. Fekete István is így szólítja a nála szintén tizenkilenc évvel idősebb Kittenberger Kálmánt: „Kedves Kálmán Bátyám!” - bár ez a megszólítás nála a több mint két évtizedes barátság során Kálmánkára változott. Kittenberger Kálmán (1881-1958) neki szóló címzése, pedig közvetlenebb nem is lehetett volna már. Természetesen ez a közvetlen hangvétel Cséplő Józseffel folytatott időskori levelezésében nincs meg,

\footnotetext{
7 Leskó László: Kalendáriummal a szölöhegyen. Szabad Föld 1997. április 8. 14. szám.

8 Somogyi Hírlap 2000. november 28. XI. évf. 278. szám. 3. p.

9 Sánta G. 2005: 231.

10 Cséplö J. 2011: 23.

11 Valló L. 1986: 155.
}

de az író mindig beszámol éppen aktuális munkájáról, tartózkodási helyéröl, tanácsot ad, vagy könyvet küld.

Cséplő József Fekete Istvánt korosodva ismerte meg, mikor az író már sokat betegeskedett. Azt mondhatjuk, hogy Cséplő József hasonló módon érzett Fekete István iránt, mint ahogy Fekete István a nagy tapasztalattal rendelkező mentor Kittenberger Kálmán iránt. „A Kittenbergerről való beszédnek a feltétlen tanítványi alázat és rajongás a kiindulópontja. Én fenntartás nélkül szerettem és tiszteltem Kálmánt - vallja Fekete István.”12 „A húsz esztendővel idősebb Kitty (Kittenberger Kálmán) afféle atyai jó barátja volt, akire ő mindvégig őszinte tisztelettel tekintett."13 „Szerényebb, tisztább szívü és egyenesebb embert nem ismertem." - írta Kittenberger Kálmánról szóló megemlékezésében Fekete István.

„Fekete István a személyes hitelével állithatja, hogy Kittenberger roppant önérzetes és szókimondó volt. (...) Jellemes emberként roppant nehezen viselte a hízelgést és az alakoskodást. (...) Kittenberger Kálmánra sokan azt mondták, hogy 'nehéz ember'."14 Azonban mint tapasztalhatjuk, a 'nehéz ember' jelzővel azokat szokás illetni, akik nem elégszenek meg a szokványos hétköznapi szakmai színvonallal és életvitellel, hanem a szakterületük iránti elkötelezettségből ennél lényegesen többre törekszenek, eközben a hitványt nem dicsőítve. Fekete István írja Kittenberger Kálmánról szóló életrajzi regényében: „csak a kilincsekkel volt baj: nem tudott kilincselni! Nem tudott dörgölődzni, és nem tudott hajlongani". E jelzők olvasása kapcsán egy pillanatig sem lehet kétséges előttünk, hogy mi volt az a kötelék, ami ennek a két nagyszerü embernek az életét összefüzte.

A téma kapcsán meg kell emlékezni gróf Széchenyi Zsigmondról is. És nem pusztán azért, mert Fekete István barátja volt, és mert Ö volt hívatott újra gyűjteni Kittenberger Kálmán az 1956-os forradalom alatt elpusztult Afrika gyűjteményét, és mert vadász, író, és mert mezőgazdász is volt, hanem annak okán is, hogy Fekete István naplójában Széchenyi Zsigmond kapcsán fejti ki a humánumról és a politikáról alkotott véleményét. „Fekete István és Széchenyi Zsigmond kapcsolata 1947 után mélyülhetett valódi barátsággá, amikor munkatársak lettek a Magyar Állami Erdőgazdasági Üzemek (MÁLLERD) vadászati osztályán. Két év múltán azonos sorsra jutottak: osztályidegenként mindkettőjüket elbocsájtották."15

Fekete István naplóbejegyzésében Széchenyi Zsigmonddal kapcsolatban az emberség elsődlegességére utal: 1968. augusztus 13. I: N: D ${ }^{16}$ : "Zsiga, 1926. gróf, a nagy Széchenyi név hordozója. Ideál, aztán jó barát, protektor s később általam protezsált. Minden és mindennek ellenkezője is, való valóság... (...) Az embernek Emberhez való viszonya. Időben, térben, személyi vonatkozásban, megvilágítva a kort, a válto-

\footnotetext{
12 Sánta G. 2005: 259.

13 Valló L. 1986: 152.

14 Sánta G. 2005: 253.

15 Sánta G. 2005: 233.

16 I.N.D.: In Nomine Dei: Isten nevében
} 


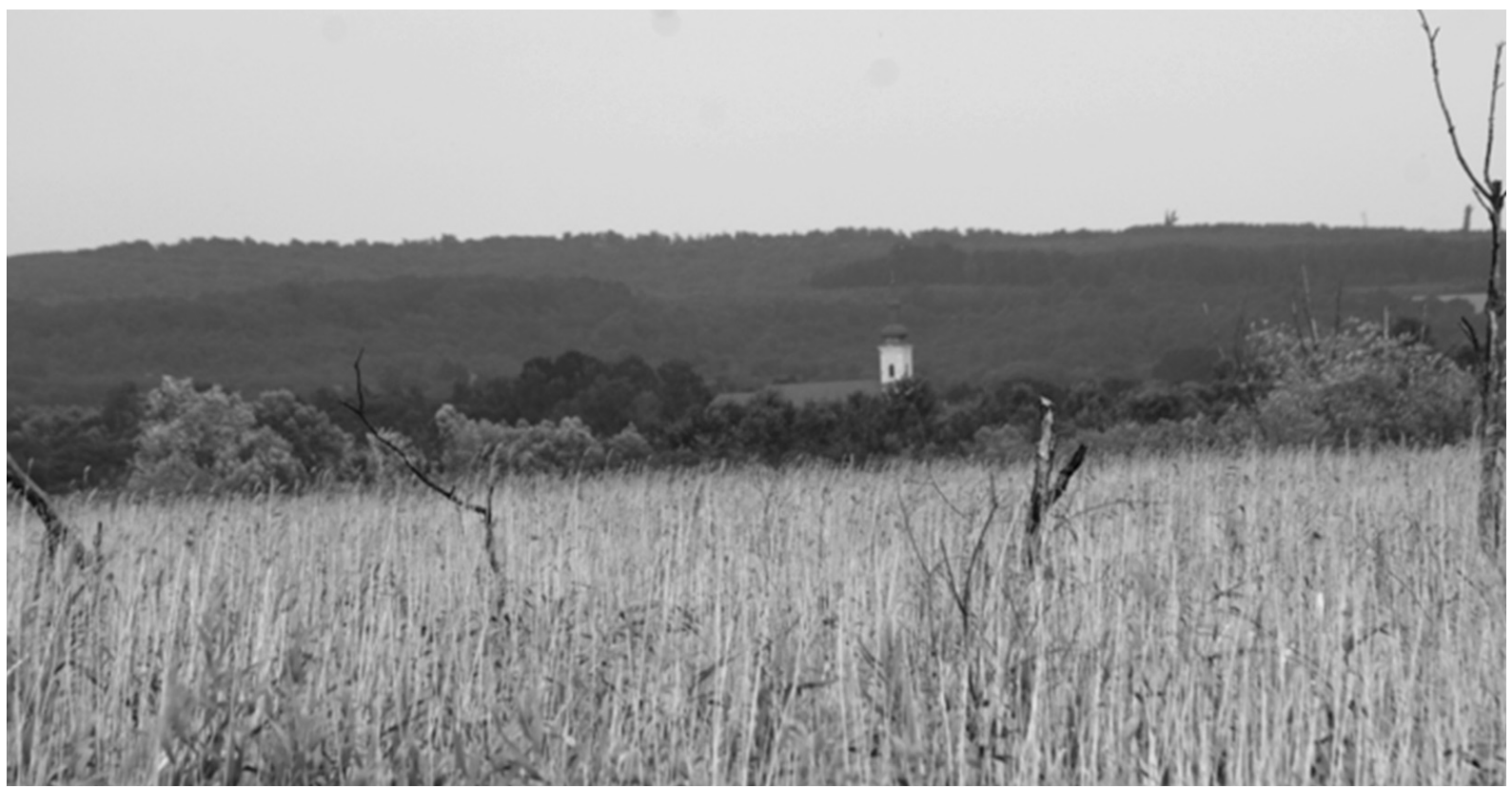

3. ábra. A Kis-Balaton Diás-szigetéröl a nádtengeren keresztül, a távolban Vörs templomtornya látható

zásokat - világrengető változásokat -, a magatartást, nemcsak - persze elsősorban - vadászi és vadászati tekintetben - hanem a humánum változhatatlan szempontjából is."17 A következő naplóbejegyzés is Széchenyi Zsigmondhoz kötődik. Egy rádióinterjú kapcsán Fekete István politikáról alkotott véleményéről szerezhetünk tudomást. 1968. szeptember 4. „Irányítani és „szocialista szemszögölni” azonban nem hagyom magam. Ilyen beállítású müsorban én semmi szerepet nem tudok és nem is akarok vállalni!!”18 „Fekete István kívül maradt e politikai-társadalmi gyürkőzéseken, egyénisége és írói útja egyaránt másfelé viszik."19

Fekete István ugyanúgy nem kívánt egyik rendszer politikájába sem belefolyni, mint ahogy Cséplő József sem. „Politikával nem foglalkozott sohasem, de a somogyi lankák szeretete meghatározták az érzelmeit és kijelölték a témáit."20 Cséplő József az 1989-es rendszerváltást követően is kimaradt a politizálásból (bár hívta az egyik párt tagjai sorába, mivel tudták, hogy a termelőszövetkezetbe sem lépett be). Számára is a humánum és a munka volt az elsődleges. Cséplő József mindenkiben csak a jót feltételezte, mértéktartó, külső megjelenésében mindvégig egyenes tartású ember volt. „Jelszava, kimondatlanul is az „Ora et labora!" (Imádkozz és dolgozz!) volt. Nagy lélek volt, mindenkihez szeretettel, jóindulattal fordult, befogadott mindenkit". - Emlékezett vissza Szalai Jeremiás címzetes prépost, göllei lelkipásztor 2016 júliusában.

Közös jellemvonásuk volt mély vallásosságuk is. Cséplő József minden vasárnap részt vett Fonóban a szentmisén, baloldalt az orgona mellett foglalt helyet.

17 Ifj. Fekete I. 2004: 209

18 Ifj. Fekete I. 2004: 214

19 Valló L. 1986: 158.

20 Somogyi Hírlap 2000. november 28. XI. évf. 278. szám. 3. p
Kivételt képezett a szőlőszemzés napja, amikor a szőlőhegyen éjszaka is füteni kellett az oltványok számára. A taszári hegyről szombat délutánonként jött viszsza Fonóba, a faluban mindenki számára ismerősen zörgött a lovas szekere. Mindaddig így közlekedett „amíg el nem aggott a rúd mellöl a szürke ló”. Később ezt az utat már autóval tette meg, balesete után pedig fia hozta-vitte. Ahogy beérünk Fonóba egy nagy kanyart követően, rögtön az első ház udvarán egy kereszt látványa tárul elénk, majd a következő udvarban úgyszintén. E két kereszt állít emléket a betegségben és háborúban elhunyt családtagoknak. „Amikor Jóska bácsi megérkezett Fonóba, soha nem mulasztotta volna el, hogy tisztelettudóan kalapot ne emeljen mindkét kereszt elött". - Emlékezik vissza Nyerges Péter, Fonó polgármestere.

A téma és nem a kronológia alapján idézem ide Fekete István itt bemutatásra kerülő 10 . levelét, amiben utal a Kis-Balatonra. Mikor huzamosabb kutató munkája során itt tartózkodott, vasárnaponként maga is begyalogolt Vörsre, a szentmisére a nádason át. (3. ábra) ${ }^{21}$ „A Diás-szigeten lévő, jelenleg Fekete István Emlékhelyként ismert egykori kutatóház és Vörs távolsága légvonalban 4 km-re tehetö. Az akkoriban még lecsapolt állapotban lévő Kis-Balatonon gyalogszerrel vágott keresztül" - mondta el Fejes Éva a Balaton-felvidéki Nemzeti Park öko-turisztikai referense. Aki csak kicsit is ismeri az író világról alkotott felfogását, azt szükségtelen győzködni Fekete István mély vallásosságáról.

Cséplő József személye volt tehát az egyik kapocs Somoggyal, a szülöfölddel, az idősödő Fekete István számára, és ebben a kapocsban Jóska bácsi szeretetteljes őszinte törődését Fekete István kitűnő emberis-

21 A vörsi templomot a nádason át Lanszki Péter fényképezte. 


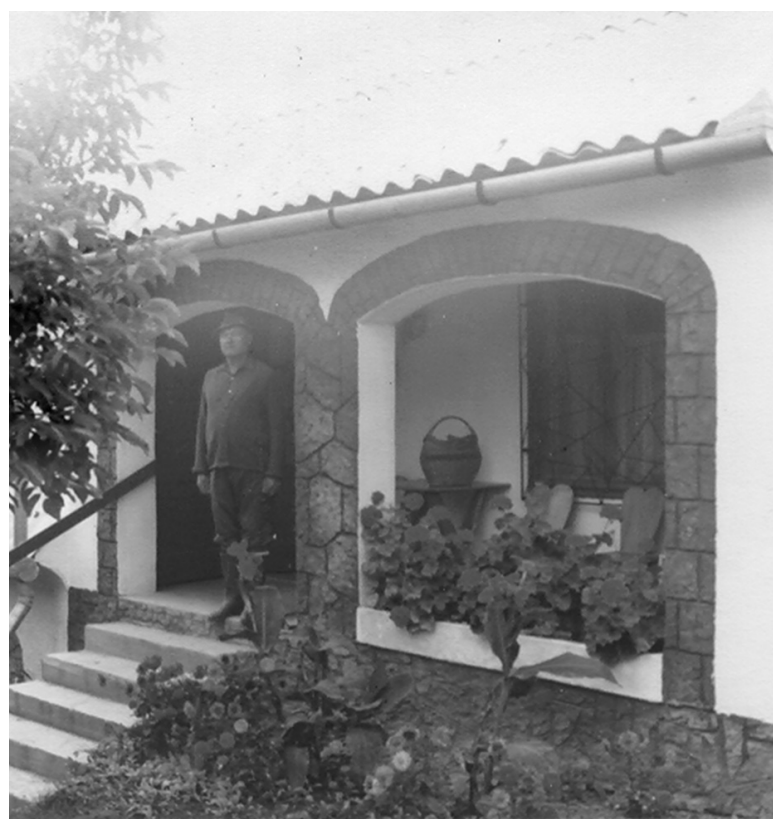

4. ábra. Cséplő József présháza a Taszári hegyen

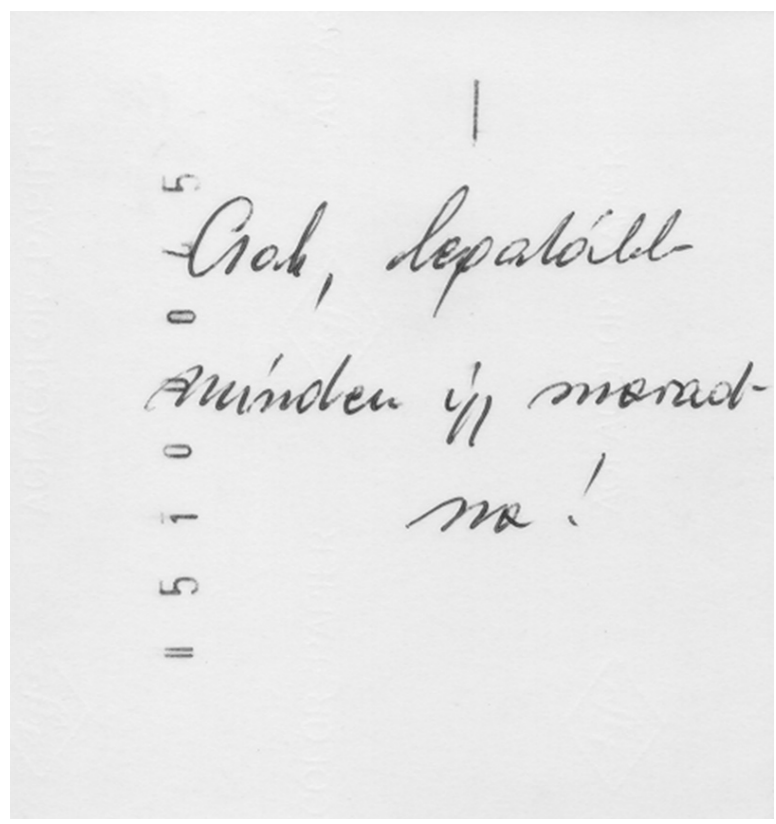

5. ábra. A présházról készült fénykép hátoldala merettel megérezte. Cséplő József gyakran vigasztalta a mind sürübben betegeskedő Fekete Istvánt, aki több esetben szabadkozásként írja, hogy miért rövid a válasz, vagy miért késett. Cséplő József az őszinte tiszteleten túl, feladatának tekintette, hogy példákkal alátámasztva a gyógyulásba vetett hitet erősítse Fekete Istvánban. (6. levél)

Cséplő József pedig hívta és hívta rendületlenül, mert őszintén szerette volna vendégül látni Fekete Istvánt (2. levél). „Mint ahogy, nagyon sokakat vendégül is látott a Taszári hegyen (4-5.ábra) lévő szőlőjében. Korra, rangra, beosztásra való tekintet nélkül. Neves kortárs írók is látogatták." - Emlékezett vissza Ballay Attila ny. tanszékvezető, aki rendszeresen felkereste barátaival és rokonaival együtt Cséplő Józsefet. Olyan alkalom is volt, hogy főiskolás hallgatókkal látogattak el Jóska bácsihoz. Az elsőre, így emlékezett vissza:,Letettük az autót és gyalog, torony iránt, neki a hegynek. Az egyenes, szókimondó embereket szerette. Csak az embert nézte." Nem számított politikai hovatartozása sem, hiszen még azokat az orosz katonákat is vendégül látta, akik korábban fogva tartói voltak, reggelig vigadtak nála. ${ }^{22}$ Pedig épp az 1956-os forradalmat követően költözött a Taszári hegyre, mivel azt tanácsolták neki, hogy tűnjön el, ha jót akar, ne legyen szem előtt. ${ }^{23}$

Fekete István leveleiben gyakran található utalás a csomagküldemények megköszönésére. Karácsonykor fenyőfát, disznóölések idején Cséplő József disznótorost küldött Fekete Istvánnak. Volt olyan eset, hogy a hosszabb ideig vidéken, nem budapesti lakásán tartózkodó Fekete István utólag következtette ki, hogy

22 Jeremiás atya szóbeli közlése.

23 Dr. Ballay Attila szóbeli közlése. kitől is származhatott az ajándék (12. levél). Ezek minden esetben szívből jövő figyelmességek voltak. Jóska bácsi nem mindennapi jószívüségének magam is szemtanúja voltam, amikor a 2010-es év szüret táján - ekkor Jóska bácsi már a 90. életévén túl volt - a taszári hegyről szüretelt csemege szőlőjét személyesen vitte Fonóban rokonainak, barátainak, ezzel is a meglévő összetartozásukat erősítette. Fekete Istvánnak is szívesen küldött volna, ahogy erröl a 6 . levélben is megemlékezik.

Ha Fekete Istvánnak fizikai munkát igénylő segítségre lett volna szüksége, Jóska bácsi bármikor rendelkezésre állt volna (2. levél). Ezt támasztja alá Hodics Gyula Somogy megye gazdasági főfelügyelöje, akinek szintén a taszári hegyen volt 'présházas valódi szőlőbirtoka' ahogy emlékirataiban írja: „Nagyon szerettem ezt a kis és kies tanyát, mert annyira szép, annyira megkapó a táj bája, a hegy hangulata. Talán két napra való pihenésem nem volt, hogy egyszerüen nem értem rá pihengetni, és így csak a kapanyélre támaszkodva, izzadó üstökkel nézegettem a gyönyörü panorámát, ami elém tárult. (...) Cséplő Jóska barátom, második szomszédomról is meleg szeretettel emlékezem meg, mert ő is olyan sok szívességet nyújtott, ősszel beszántotta a szőlőt, segített mindennel, amire csak szükségem volt, hozzá sem fordulhattam úgy, hogy valamit is megtagadott volna tölem." ${ }^{4}$ Jóska bácsi 92 esztendősen is fáradhatatlanul művelte a taszári hegyen szőlejét még 2011-ben is.

Éppen ezért közös Fekete Istvánnal az is, hogy mindkettejük munkabírása határtalan volt. Édesapjáról a következőket írja Ifj. Fekete István: „Milyen erős belső sürgetés kényszerítette őt az írásra? Tudom jól,

24 Hodics Gyula emlékiratai. 319-320. p. Kézirat. 
a pályázat csak alkalom volt arra, hogy megírja mondanivalóját, mely minden dicsőségkereséstől távol, ott élt a lelkében." ${ }^{25}$ Fekete István ezt így fogalmazta meg barátairól naplójában, pontosan úgy, ahogy aztán az vele is történt: „1968. szeptember 4. ... csak akkor hagyták abba, amikor az elmúlás szelíden kivette kezükből a tollat." ${ }^{26}$ A leveleket olvasva, mindezek egyértelműen kiderülnek számunkra.

\section{Cséplő József és Fekete István levelezése}

Fekete István első fejléces válaszlevele, amely Cséplő József meghívására íródott. A természettel való különleges kapcsolatot, az ember ide való menekülését - ha csak lélekben is - Fekete Istvánnál szebben nem fogalmazta meg senki. Ezért is rajonganak érte oly sokan, mert ami gondolatot mi nem tudunk szavakba önteni, azt megteszi helyettünk Fekete István az író. Cséplő József ezt így kéri Fekete Istvántól a 3. levélben: „magas szellemi horizontodról láss el még bennünket sok-sok szép, kedves könyvel." Fekete István válaszában visszautal a kedves meghívásra és mindjárt szabadkozik is az miatt, hogy a 'csábítás' dacára nem tud a kérésnek eleget tenni. Tény, hogy az írót sokan és sok felöl ostromolták a legkülönbözőbb meghívásokkal, amire egy alkalommal - éppen Somogyból, Bánki Gyula (1909-1976) kaposvári könyvtárvezetőnek - a következő szellemes választ írta: „... arra döbbennétek rá Ti is, amit Mikszáth mondott, és utána sokan vallották, hogy «az író olyan, mint a havasi kürt, csak messziről szép»."27

Cséplő József erre a levélre, így válaszolt: „Kedves Pista bátyám! Engedje meg, hogy a tiszteletből és szeretetből fakadó közeledésnek, eme bensőségesebb hangján szólítsam meg. Nem tagadom, nagy örömöt szerzett kedves levele. De majd csaknem fölért az örömmel a megdöbbenésböl született keserüség! Igen nagy baj az, hogy ilyen végtelen rövidnek tünik egy emberi élet, és az idő múlásával, a megkopott gépezet akadozik. (...)

Azonban, van egy másik segítési lehetőség a lélek világában!! A halhatatlan Örök doktor, elé terjeszteni kérésemet, mert, úgyis csak ez az egyetlen szilárd pont van a világon!! (...) A többi mind, próbálkozás, tapogatás, magyarázkodás (...). Pedig titokban remélem, megdobban majd a föld, az öregedö ember lépései alatt, itt a homoki dombokon. (...) Aztán harcol a toll, és fürgén gyorsan, táncra perdül az íróban, a hanyatló élet (...). Nem tudom hinni, hogy az egykor oly kívánatos tájak, utolérhetetlen meseországgá legyenek az Ön számára.(...)

Majd, múlik a betegség és kezd erősödni. Az erősödéssel együtt kezdenek éledni a vágyak is és, akkor majd asztalhoz ül és levelet ír nekem. Én várni fogom!! Lehet, hogy én küldök, Pestre kocsit aztán elindulnak. Ahogy mind közelebb ér az igali domboknál (...) Aztán jönnek egyenesen délfelé, addig is oda, ahol a dom-

25 Ifj. Fekete I. 2004: 328

26 Valló L. 1986:213.

27 Sánta G. 2014: 56. bok alá szorult falu mögött álmodó erdőket látni. Ha sáros lesz, az út az sem számít!! Majd (...) elébe áll, csillogó ellenfelének és segít neki! Én meg lábam közé veszem a zümmögő motor orrát, (...) De amikor már innét is kiérünk egyszerre szemünkbe nevet, a szürke. (...). Zümmögö, kaptárváros, és az öreg pince fehér homloka (...). Itt aztán újra megélénkül az élő, vagy elpihenni akaró emlékek tarka karneválja. Ennek lehet, hogy üditő életvize lesz, egy már nem is remélt életfejezetnek. (...)

Nem adom fel reményeit annak, hogy egészsége megengedi még, szelíd mámorokba való temetkezését, ott ahová az élet ezer szála füzi! (...) Tudomására kell hoznom, hogy ennek a földnek terményeiből nem marad el az emlékeztető csomag sem. Februárba Pestre megyek, és hogyha nem venné tolakodásnak örömmel meglátogatnám. Ez ügyben is szeretettel venném, és várom kedves levelét, gyors és teljes gyógyulást kívánva. Mély üdvözlettel, Cséplő József' (2. levél).

Békés Sándor vadászíró írja Fekete István Cséplő József levelezése kapcsán: „Találok egy másik levelet, melyben Fekete István Cséplő Józsefnek arra a levelére válaszol, melyben könyveket kért töle. A dátum: 1964. I. 6. ... «A háború előtt megjelent könyveimből csak egy-egy példány van, s azok ma már pótolhatatlanok. A háború utániakból most csak a Kele, Bogáncs, Lutra, A Koppányi aga testamentuma és a Tüskevár azok, amelyekböl felesleg van. (...) Végül azt írod, hogy áráért ... hát erröl nem lehet beszélni. Ami van, készségesen küldöm szeretettel és nem áráért ... »"28 Ez a levél sajnos nem található a Cséplő-féle hagyatékban, de valószínüleg időrendi sorrendben ez a levél következne. A tegeződésük már a találkozás előtt megtörtént a levélváltások során.

„Kedves Pista bátyám! Nem próbálok szavakat keresni, hogy formába öntsem az örömöt, amit négy szép értékes könyved nálunk szerzett. Őszintén megmondom egyre számítottam és négy jött. Csak egy szót tudok írni, amiben benne van családom minden egyes tagjának, feléd sugárzó szeretete „köszönjük”. További örömöknek sietünk elébe, ahogy írod, mert majd nem sokára olvashatjuk a Hu-t. Kívánom, hogy munkakedved soha ne hagyjon el és magas szellemi horizontodról láss el még bennünket sok-sok szép, kedves könyvvel. Nagyon köszönöm a szigorú megkülönböztetést (...). Most már pontosan meg tudom írni a Pesten való tartózkodásom idejét. E hó, azaz február 14.-én délután 6 órakor, szeretnék egy kis időt Nálad tölteni. Nem tudom, hogy mivel a napot, az órát is megírtam lesz-e szükség telefonra. A fenti dátum látogatásomat illetően nem hiszem, hogy változik, mert a Kislányom avatása lesz 15-én, az Orvostudományi Egyetemen, és 14-én utazok föl. Ekkor estefelé lenne nekem a legalkalmasabb a látogatás. Nagyon kérlek, ha lehet, fogadd el ezt az időpontot mer később egy vacsorán kell megjelennem, másnap meg az ünnepség után haza szeretnék jönni.

28 Békés S. 2009: 582. 583 


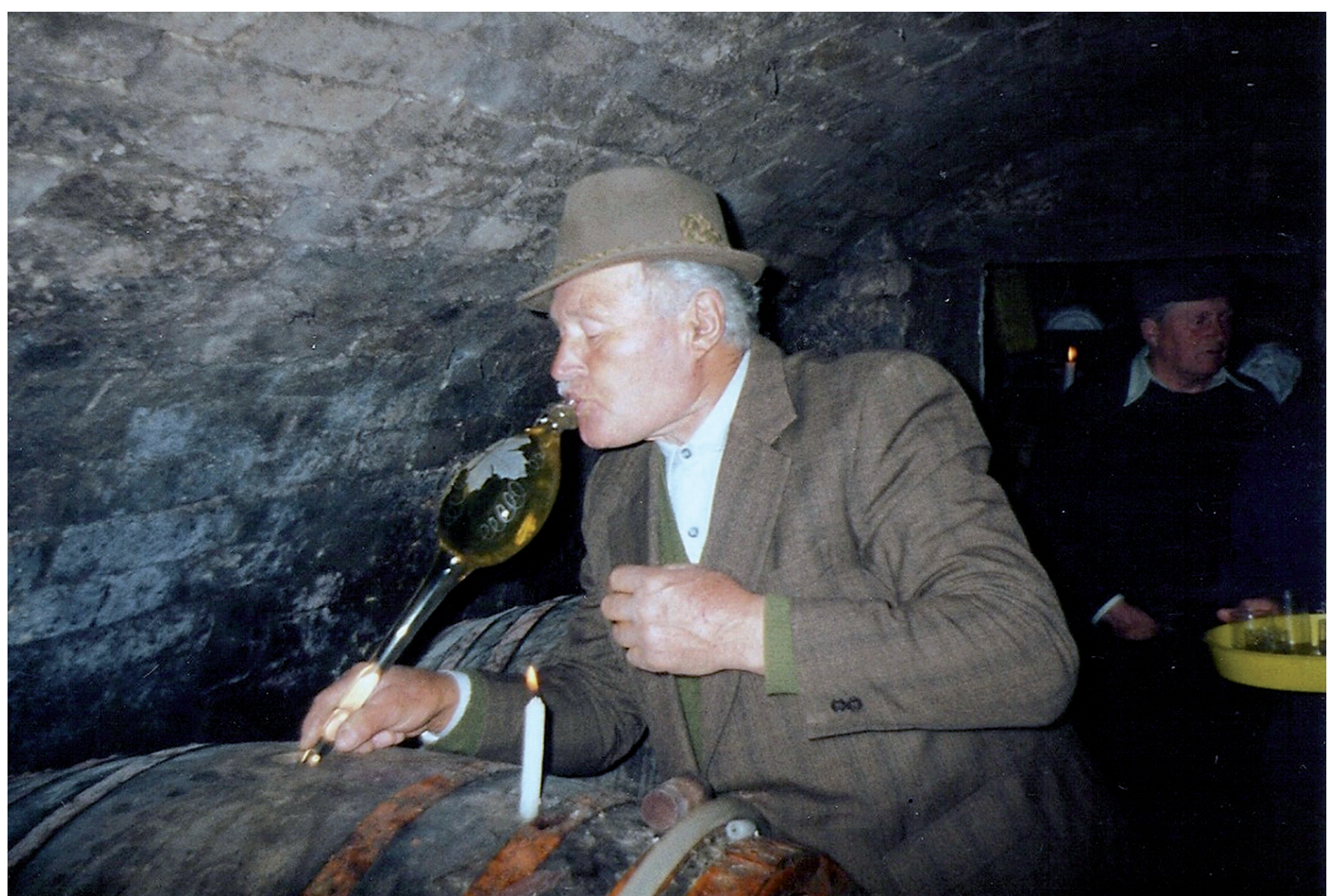

6. ábra. „Nagyon hívott, de túl jó borai vannak...” - írta Fekete István a naplójában

Kedves Pista bátyám, a tél most már úgy viselkedik, mint egy farsangi vén legény. A dombok fehér hósapkáját (...) Az erdőn néha olyan szépen muzsikál a szél, mintha búcsúztatná ezt a farsangi vénlegényt. A megduzzadt patakok hangos csobogásában, mintha már, a korai tavasz gyermek sírását hallanám. Még egyszer megköszönöm kedves ajándékodat, a csomag tartalmához jó étvágyat, és megegészségedést kívánva, sokat gondol Rád, és egyszer csak bekopog nálad: Cséplö József." (3. levél).

Erre a levélre küldött válasz a következő: „Kedves Barátom, újabb kedves küldeményedet megköszönve értesitlek, hogy febr. 14.-én, 6 órakor szeretettel várlak. Hived: Fekete István." (4. levél).

Békés Sándor egyik Cséplő Józsefnél tett látogatása kapcsán írja: „Nézzük a lámpafényben az aranyló bort, s nekem Fekete István 1964. február 15-én kelt naplóbejegyzése jut az eszembe, melyre dr. Bod Lajos hívta fel a figyelmemet: "Cséplö József látogatott meg Fonóból. Ilyen lelkes melegszívü parasztembert Göllében sem láttam. Nagyon hívott, de túl jó borai vannak (6. ábra) és én túl gyenge vagyok ellenállni a szabadságnak és a mámornak. Tehát nem megyek.»"29

Amikor Cséplő József azt írta, hogy „Kislányom avatása lesz 15-én, az Orvostudományi Egyetemen ..." annak hátterében az állt, hogy lánya Cséplő Márta ekkor végezte el az Orvostudományi Egyetem gyógy-

29 Békés S. 2009: 582. 583. szerészeti szakát Budapesten. Jóska bácsi egy beszélgetésünk során elmondta ,jobban örülök, hogy a kislányom gyógyszerésznek tanult, és nem orvosnak, mert egy orvosnak mekkora lelki teher lehet az, ha egy betegét elveszti. Egy nőnek még nehezebb lehet ezt elviselni, mint egy férfinak."

„Kedves Jóska! Megint elmaradtam a válasszal, de súlyos okaim vannak rá, mert komolyan beteg vagyok. A szívem rendetlenkedik és idegeim egészen gyenge állapotban vannak. Sokat fekszem és gondolataim mélyen deprimáltak. A könyvem sem tudom folytatni, állandóan orvossággal élek, egyszóval: szomorúan elesett vagyok. Hát ezért nem írtam, ezért írok csak ilyen röviden. Szeretettel ölel: Fekete István 1964. VIII. 9." (5. levél).

Cséplő József következő levelében (6. levél) utalást tesz a méhek kapcsán Úzd pusztára. Gölle szomszédságában fekvő Úzdon voltak Fekete István gyermekkorában a tanítói illetmény földek, amiben Édesapja is részesült. Jóska bácsi is valószínüleg jól tudta ezt, nem véletlenül írta éppen Úzdot a méhek vándorútjának példájául.

„Drága jó, Pista bátyám! Fájdalmas megdöbbenéssel vettem, rövid leveled, amelyben tudatsz újabb betegséged felöl. Pontosan az ellenkezőjére számítottam, a bennlévő hírek, a boriték felbontása előtt. Nem volt olyan nap, amelyen ne gondoltam volna Rád, és minden munkámat, valami lázas készülődés jegyében ne végeztem volna. Majd egyszer csak jössz! A forró 


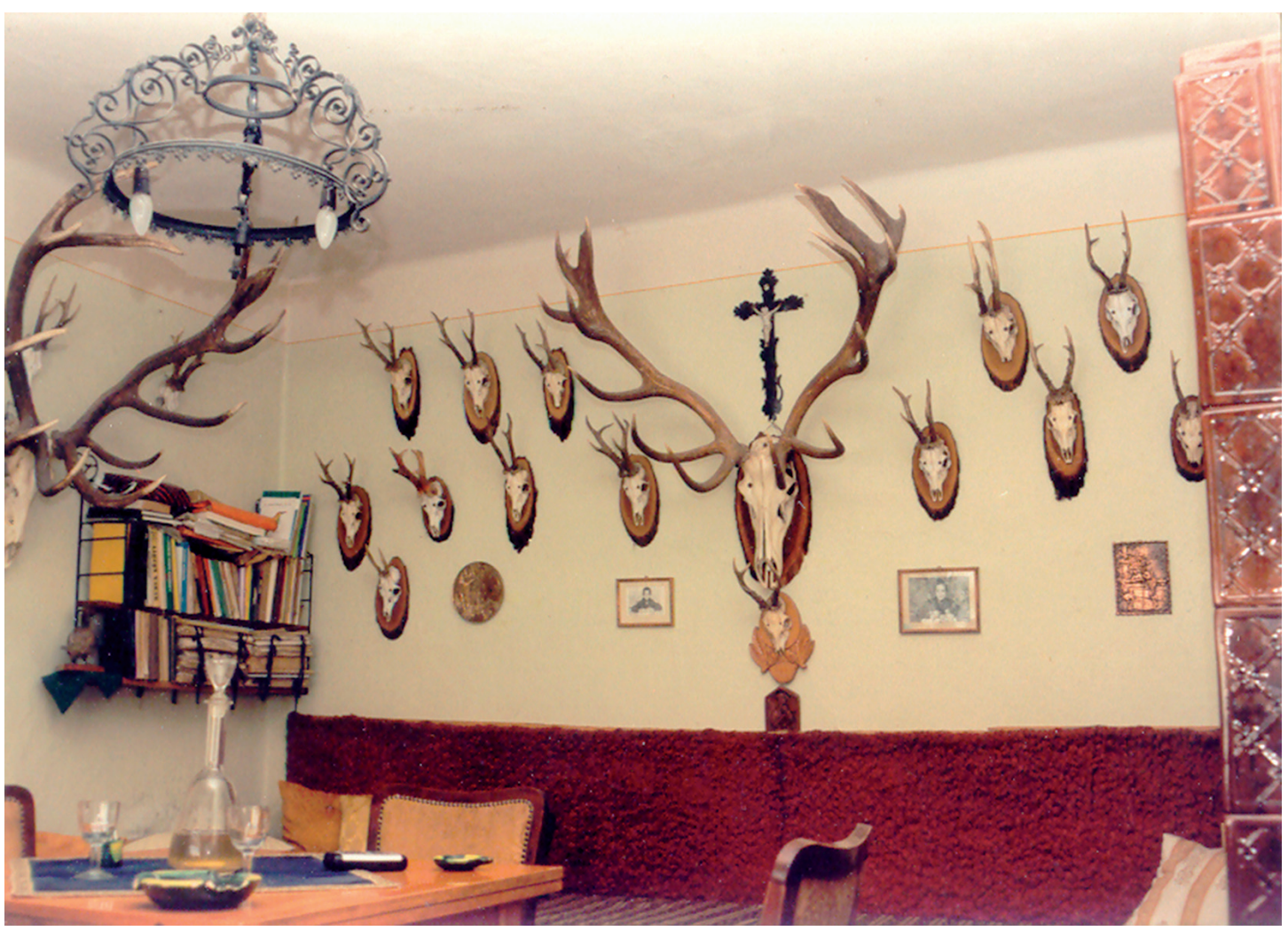

7. ábra. Cséplő József trófeagyüjteményének egy része

\section{Iana Käzség Diszpalgara Kituntetácim}

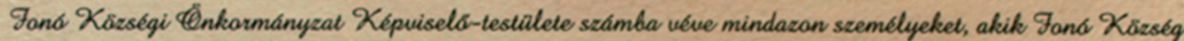
felviragactatasáert, tarsadalmi, gazdasági, tudamanyas, scacialis, aktatasi, mëvésceti, kulturalis és sportéleti

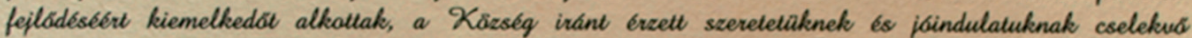

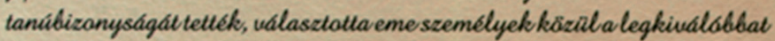

\section{Cosple Yocsef Urat,}

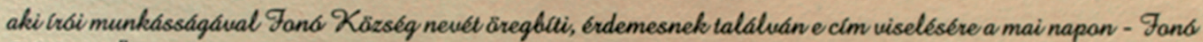

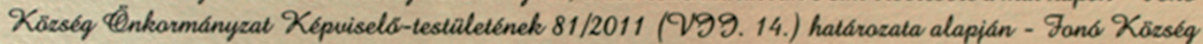
disspalgarawa ualasctoth. Ënnekemlekezetere a Képuisele-testalet nagyrabecsilese és szeretete jeleal kiadja a Köség pecsétjerelmegerdsitettjelenablevelet.

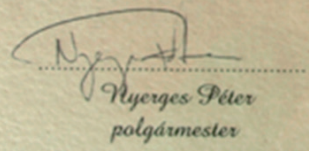

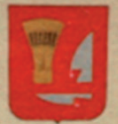

Patalintín fleso' fuibia

Palakine Keresa Sziluia

käriegyzö 
nyár közepén nem is vártalak, hanem most már igazán kezdett bennem lobogni a találkozás utáni vágyakozás. És íme, ez a levél.

Végtelenül sajnállak! Nemcsak azért, hogy egyelöre nem folytathatod könyvedet, hanem azért föképpen, hogy szenvedsz és gyötrődve gondolkodsz. Milyen csúnya hatalom ez a betegség.

Rendületlenül tudok bízni abba, hogy fölfogsz épülni. Korodnak már velejárója a betegeskedés. Aztán majd hol jobban, hol meg kicsit kellemetlenebbül érzed magad, amíg aztán hosszabb időre, és kilépsz a betegség büvköréböl. Összel is ki szokott sütni a Nap, ha már melege fogyófélben is van.

Az itteni világról is valamit. A méhek még vándorúton vannak Úzd térségében a tarlóvirág fehér szirmai között tarkállva szedegetik a télire valót. Reggel már későn indulnak, este korán hálnak, érzik, hogy elmúlik a Nyár, és hamarosan eljön valami.

A szőlő most már elő van készítve a szüretre és úgy néz ki, mint a nagylányok vasárnap délután. Tiszta csábító!

Az őszi arcú Nap, langyos fényénél teríti be a szépen fölkapált sorokat, ahol a Nyár érlelte szőlőfürtökben (...). Ebből a gyógyszerből szívesen viszek Neked, hogy ha fölmegyek Pestre, a Mezőgazdasági Kiállitást megnézni. Szőlőt szállítani postán nem lehet, mert nagyon összetörik. Írd meg, hogy szabad-e fogyasztanod?

Jól tudod az erdő ilyenkor csendes. Az őzszerelemnek vége, és a szarvasok sincsenek még lázban. De majd eljön az ideje, annak is megzendülhet az erdő az egyik szélétől a másikig. Gyors és teljes gyógyulást kívánok, szeretettel ölel: Cs J." (6. levél).

Ismét egy párhuzam és kapcsolódás kettejük életében, merthogy mindketten képzett mezőgazdászok voltak. „Fekete István rátermett agrárszakember volt, aki e felelösségteljes munkához nélkülözhetetlen érzékkel, szorgalommal és tudással egyaránt rendelkezett."30 Fekete István ugyancsak egy levélben - amit Halmai Józsefnek írt 1936 februárjában - erről így vall: „Tudod, hogy szeretem a földet és szeretem a pályám. Ha még egyszer születnék is csak gazdász vagy erdész lennék, de azért jólesne egy-két szabad óra, hogy titkos szerelmem, az írást, a Múzsát gondtalanul átölelhessem."31

A 6. levélben utalást találunk Cséplő Józseftől, hogy „fölmegyek Pestre, a Mezőgazdasági Kiállitást megnézni." Cséplő József édesapja is ugyanúgy hozott haza díjat 1933-ban és 1934-ben, mint Fekete István Édesapja. Cséplő Lajos bikaborjú elismerő oklevélben részesült. ${ }^{32}$

1909 augusztusában alig két hónappal az után, hogy az Országos Állatkiállításról első díjat hozott haza Fekete Árpád tanító és gazda, Fekete István író édesapja Gölléből írt levelet a Gazdasági Felügyelőségnek, annak érdekében, hogy teheneit Fonóban vihesse fedeztetni. A fonóiak tenyészbikája Széll Kálmán miniszterelnök kitűnő tenyészetéből származott (7. levél).

30 Sánta G. 2005: 84.

31 Sánta G. 2015: 112.

32 Kiss E. 1935: Kigyűjtés
„Tekintetes Felügyelő Úr! A Fonóiaktól úgy értesültem (...) ha lenne kegyes és 2 drb marhám fedezését megengedné! lgaz, a marháimat el akarom adni, de azért mégis szeretném, ha érdemes bikával lennének befedezve. Szívességét elöre is köszönve vagyok Tekintetességednek kész szolgája. Gölle, 1909. VIII. Fekete Árpád tanító" ${ }^{33}$ Fekete Árpád a teheneket valóban eladta, mert 1910-ben Kaposvárra költözött, de hogy a Széll-féle bikával lettek-e fedeztetve a tehenei, az most nem derült ki. ${ }^{34}$

Cséplő József szakszerü visszaemlékezésével nagyban segítette Fonó országos hírủ állattenyésztési múltjáról szóló történetek összegyűjtését. Egy-két kiragadott mondatot érdekességképpen idézek tőle.

A két világháború között folytatódott a szimentáli behozatala Svájcból. Nem mindennapi pillanat lehetett, amikor a batéi vasútállomásra begördültek a Svájcból importált hasas üszőket, tízmázsás tenyészbikákat szállító vagonok. „Magyarországon azelőtt ilyen nem volt! A fonói gazdák egy import tehenet mindenképp, de a módosabbja kettőt is vásárolt! (...) A tenyésztésbe fogott elöhasi üszöket törzskönyvi ellenőrzésbe vették. (...) Az 5000 I tejhozamú teheneket nem nagyon szerettük, mert hamar kimerült a szervezetük. 3800-4200 I tejhozamút szerettük. Ez a laktációs tejtermelés felelt meg a gazdaság és a tehenek teherbíró képességének egyaránt, így tovább tenyésztésben tudtuk tartani a teheneket, többször, 7-8-szor fogott borjút. (...) Kedveztünk a teheneknek, az ember is megehette volna, ami takarmányt biztosítottunk számukra. (...) Még Erdélybe is vettek meg bikákat Fonóból. (...) A gazdák többsége rokon volt egymással, a rokonság pedig öszszefogó természetü, kasztokba tömörültek, ami a minőségi állattenyésztés hasznára lett. (...)

Ha engedte a dolog, szombat délután vagy vasárnap hajnalban - de misére mindenki mindenképp elment-, húsz bikát is kivezettek egyszerre, hogy szokják meg egymás jelenlétét, mire a kiállításra kerül a sor. A szépség érdekében a bika fejét samponnal mosták, hogy szépen göndörödjön a csigaszöre. A szarvát üvegcseréppel kismirglizték, zsírral bekenték, csak úgy ragyogott! A csülkét szalonnabörrel kenték ki. A bika megjelenése így igen ápolt benyomást keltett."

Az előbbi visszaemlékezésekből is jól érzékelhető, hogy milyen összetett, sokrétű feladata volt a gazdáknak a minőségi szarvasmarha-tenyésztés teljes folyamatában." 35

A 8. levélre már rányomta bélyegét az idő kíméletlen vasfoga. Minden bizonnyal Jóska bácsi egyik kedvenc levele lehetett, hiszen Fekete István őt illető pozitív kritikája olvasható benne. Fekete István ebben a levelében tudatja Cséplő Józseffel, hogy a Hú-t írja, sőt egy "költői kérdést» is feltesz: „mit lehet egy bagolyról 400 oldalon írni?" Ez a dilemma Csermely Ottóné Bartáky Editnek 1964. január 7.-én írt levelében is foglalkoztatja: „(...) persze nem egyszerü dolog egy bagolyról 400-500 oldalt írni, és sokszor már arra

33 MNL. SML. GFI. 1909. augusztus. Fekete Árpád levele.

34 Lanszkiné Széles G. 2013: 68.

35 Uo 
gondoltam, hogy kisebb fába is vághattam volna a fejszémet." 36

De térjünk vissza az eredeti levél tartalmához! „Kedves Barátom! Elnézésed kérem a (...) válaszért, de nagy állatregényemet a „Hú”-t írom, nehezen (...) kiszakadni belőle. Szóval! Leveled (...) pénzzel együtt rendben megérkezett, sőt írásoddal együtt, amiről csak jót mondhatok. Tiszta, világos, szabatos és magyaros. Talán anynyit mondhatnék tanácsként, hogy - ha lehet - (...) még rövidebben írni. Ha írás közben erre gondolsz, maguktól lehullanak a sallangok, amelyeket más talán (...) sem vesz, de feleslegesek. Egyébként különös újság nincs. Legfeljebb az, hogy: fáradt vagyok. Nehéz írás (...), mert mit lehet egy bagolyról 400 oldalon írni? Köszönöm a (...) ezévben már aligha lehet róla szó, mert írásomat (...). Ha Isten is úgy akarja talán majd jövöre. Szeretettel köszönt öreg híved: Fekete István." (8. levél). A bagolyregény végül 1966 júliusának közepén látott napvilágot, melynek bekötött kéziratát Bodó Imre dombóvári magánmúzeuma őrzi. ${ }^{37}$

\section{„Kedves Pista bátyám!}

Leveled a szép ünnep közepén ért, úgy hozták ki ide utánnam. Nemcsak azért volt szép az a nap, mer Piros Pünkösd volt, hanem azér is, mer kedves leveled mindig ünneppé avatja azt a napot, amikor kezembe vehetem. Na meg azér is ünnep volt, mer a leveled érkezésének napján, belefordultam a negyvennegyedik életévembe. Bizonyára, ha ezt olvasod, legyintesz egyet, és azt mondod, - „hej ha én még annyi lennék?!” Most még csakugyan nincs baj, mer még mindent meghagyva, csak maguk az évek (...) észrevétlenül (...). De, amikor már majd mindegyik elvisz valamit!!

Nagyon köszönöm a kedves kritikát, ami inkább dicsér, mint kritizál. A továbbiakban sokat érő tanácsod szerint járok el. Örülök, hogy készül a Hú, bár kissé féltelek a fáradtság miatt. Olyan szívesen küldenék ebböl a tüzes Zselici tavaszból, egy nagy csomagot, de nincs olyan csomagolópapír, amelyből meg nem szökik Budapestig. (...)

De ez is csak úgy jár szerintem, - lassan megöregszik. A kökénykoszorú már rég elhervadt a Tavasz, glóriás fején, és az esti szél már megfonnyadt akácszirmot szór a közelgő Nyár elé, - (...) a szőlő is virágzik már. Az özek vörösbarna bundája is azt jelzi, hogy fölkészülünk a nyári karneválra. Nagyon szeretheted a szarvasokat, hogy már egy évvel meg is hosszabbitottad az életét a neked szánt vén betyárnak." (9. levél). Sajnos hiányzik a levél folytatása, Jóska bácsi egy kis szomorú humort is belefogalmazott a levelébe, miszerint Fekete István ez évben sem látogatta meg, így a vadászat az idén is elmaradt.

„Kedves Barátom! (.....) jóleső megemlékezésed hálásan köszönöm és kívánok békés, boldog karácsonyt szerencsés egészséges új esztendőt! Szeretettel: Fekete István. U.i: Ha újabban megjelent könyveimből valamelyik hiányzik, kérlek írd meg." (11. levél).

Fekete István és felesége a hatvanas években rendszeres vendége volt a szigligeti alkotóháznak, ami a

36 Sánta G. 2005: 208.

37 Sánta G. 2005: 209. csendes elvonulás és alkotás lehetőségét jelentette számára. Fekete István bal veséjét 1962 májusában eltávolították, és részben ez miatt nem emelhetett nehezet, ezért otthoni cserépkályháik befütése egyre komolyabb problémát okozott. Ez az első számú magyarázata annak, hogy a továbbiakban feleségestül a szigligeti alkotóházban töltötte a teleket. ${ }^{38}$ Lakrészük egy nagy és egy egészen kicsi szobából áll. Itt ebben a kis helyiségben, a „második Kuckóban" rendezkedik be az író, gondosan papírral fedve és szépen leragasztva a hideg-rideg asztallapot. ${ }^{39}$ A szigligeti tartózkodásra utal a következő levél.

„Kedves Barátom! Két hónapig Szigligeten voltam az Írók Alkotóházában és most hazaérve tudtam csak meg, hogy karácsonyfát kaptak, akikre a lakást bíztam, de nem tudták megmondani: kitöl. Biztos vagyok benne, hogy Te küldted, hát bocsáss meg, hogy hálás köszönetem csak most küldöm. Szeretettel üdvözöl: Fekete István 1965. febr. 8." (12. levél).

A szigligeti teleket, ritkuló vadászkirándulásokat és baráti összejöveteleket leszámítva, alig mozdult ki Tárogató úti otthonából. Leghőbb vágya az volt, hogy ne háborgassák. ${ }^{40}$ Fekete István szigligeti képeslapon küldte, következő üdvözletét. „Kedves Jóska! Jóleső megemlékezésed szeretettel köszönjük, és jó kívánságaid szívből viszonozzuk. Én márciusig a szigligeti Alkotóházban alkotom. Ismét küldök sok baráti üdvözletet. Szeretettel: Fekete István 1966. I. 8.” (13. levél).

„A 14. levél esetében ugyancsak eredeti a kézírás, a madáretetőt ábrázoló képeslapon. Évszám nem található rajta, és a bélyegzőről sem olvasható le, azonban ugyanolyan, mint Nagy Domokos Imrének 1966. XII. hónapban küldött képeslap.

„Eredeti kézírás, egy A/6 (levelezőlap) nagyságú foto karton. Hátoldalán Vertse Albert egy madáretetőt ábrázoló festményének egy fekete-fehér reprodukciója van." ${ }^{41}$

„Kedves Barátom, jóelöre nagyon boldog és békés Karácsonyi Ünnepeket kívánunk, de kérlek ne küldj karácsonyra semmit, mert áprilisig nem leszünk itthon. Szeretettel köszönt háznépeddel együtt: Fekete István"

Szigligeten a békés alkotómunka, a kedves, csendes baráti beszélgetések színhelyén éri a következő nagy figyelmeztetés, a második infarktus, 1968-ban. A füredi szívkórház hozza helyre súlyosan megrendült egészségét, és az elbocsájtó orvosi javallat a tilalomfák sorát állítja a súlyosan megsebzett szívű írónak. ${ }^{42}$ A 15 . levélben olvashatunk erről a „komisz szívrohamról'. Cséplő Józsefet tanáccsal látja el kiadandó könyvét illetően.

A 16. levél évszám nélküli. „Kegyelemteljes húsvéti ünnepeket kíván Fekete István” (16. levél). A hatvanas években (ahogy múlt az idő, egyre inkább) nehezére esett - akárcsak egy levél erejéig is - kilépnie az ép-

\footnotetext{
38 Sánta G. 2015: 191

39 Valló L. 1986: 160.

40 Sánta G. 2005: 221

41 Saját írásommal Fekete István szövege fölött: Érk. 66. XII. Lényegi részét közöltem: Nagy Domokos Imre: A vadászirodalom.Bp. Terraprint, 1996. 5. old. [Budapest, 1966. december] Fekete István levele Nagy Domokos Imréhez Fekete István levelezéséből EPAepa.oszk.hu/.../EPA02451_Erdeszettorteneti_ Kozlemenyek_60_2003_1

42 Valló L. 1986: $17 \overline{7}$
} 
pen munkában lévő műből; s csak akkor írt levelet, ha nagyon fontosnak érezte a közlendöket. Telefonon is szívesebben beszélt. Utólag nyilvánvaló a számomra, hogy érezte: kifut az időből, és még sok mondanivalója lett volna. ${ }^{43}$

„Sürgős munkában vagyok, leveledre később megy válasz." (16. levél).

A 17.levél 1970. III. 9.-i keltezésű és válasz Cséplő József utolsó születésnapi jókívánságaira, Fekete István, itt is csak az elmaradt munkáinak pótlására tud gondolni.

Májusban Edit lányuk hívására - aki akkor már a riedenburgi Sacré Coeur zárda egyik vezetője - külföldre utaznak. Egy hónapot töltenek az Alpok gyönyörű vidékein, de a gyógyszer és a gyorsan segítő injekció már nélkülözhetetlen útitárs. (...) Hazatérve szinte pihenés nélkül folytatja az írást. Kezelőorvosa elégedett egészségi állapotával, és a Complamin-injekciót - amelyet Edith eddig naponta adott be férjének - már csak kétnaponta írja elő. A derülátó orvosi vélemény megnyugtatja. ${ }^{44}$

„... Aztán egyszerre megáll a tekintet, felszáll a sóhaj, az arc a végtelenbe dermed, és földi sötétség csordul a szemekre. (...) Fekete István 1970. június 23-án halt meg Budapesten. Haláláról megemlékeztek a napilapok, több hetilap, az egyházi újságok, természettudományos folyóiratok és gazdasági lapok. Közülük az Élet és Irodalom hasábjain Hárs Lászlótól idézünk: „Az ő világa nem a káoszból, az alaktalan gomolygásból, hanem az összhangból keletkezett. Ezért él és mozog benne oly otthonosan minden élőlény, akár állat, akár ember, akár növény. De még az élettelen is megleli benne a maga helyét. Ezért oly ritka egységes ez a világ, amelyet most már meg kell neveznem: életmü." ${ }^{45}$ „Jávorka Sándor, a tudós a magyar flórával ajándékozta meg nemzetét. Fekete István, az irodalomba emelt hazai természettel." - Írta Ruffy Péter a Magyar Nemzet, 1970. június 24.-én megjelenő számában. ${ }^{46}$

És az utolsó levél (18. levél) ami a Tárogató utcából érkezett, de aminek feladója már nem Fekete István az író, hanem az Ö özvegye. Joggal feltételezhetjük, ha Fekete Istvánné, született Piller Edith (1909-1997) külön megköszönte Cséplő Józsefnek az író elhunyta alkalmából kifejezett részvétét és együttérzését, akkor az aláíró özvegy is jól tudta, hogy ezzel a gesztussal a fonói Cséplő József személyében férjének nemcsak egy egyszerű olvasó-rajongóját tiszteli meg. A Cséplőféle hagyatékból előkerült névjegykártya (19. levél) az írótól jutott Jóska bácsihoz, de aminek „szerénysége” sem a tulajdonos iskolai végzettségére, sem a foglalkozására nem utal. Fekete István névjegykártyája minden hivalkodástól mentes .... .

\section{Összegzés}

Cséplő József már betöltötte a 42. életévét, amikor elkezdett Fekete Istvánnal levelezni, és 8 éven keresztül leveleztek. Az író elhunyta után még 42 évig akadtak neki is szorgos teendői ezen a Földön. Köztük olyan fontos eseményekben vállalt részt, mint az 1971-es Vadászati Világkiállítás szervezési feladatai. A Nemzetközi Vadászati Tanács elnöke, I.G. van Maasdijk mondta erről a kiállításról: „Magyarország vadászati múltját és jelenét, valamint a természetvédelemben kifejtett erőfeszítéseit tekintve talán a legalkalmasabb hely ennek a grandiózus seregszemlének a megrendezésére. Az országnak egész történelme során olyan magas fokú volt a vadászati kultúrája, a vadászat és természetvédelem terén napjainkban olyan tudatos, eredményes munkát fejt ki, amelyröl csak a legteljesebb elismeréssel lehet szólni." 47

Az 1971-es Vadászati Világkiállításra történő felkészülésre Cséplő József így emlékezett vissza: „A Budapesti Vadászati Kiállitás előtti évben meghívást kaptam egy egyesült államokbeli vadászatra. Pesten találkoztam Karcag Ivánnal, aki akkor a Nimród főszerkesztője volt. Hallotta valakitöl, hogy meghívásom van Amerikába. (...) A föszerkesztő felhívta a figyelmemet, hogy a baráti kapcsolatokat használjam ki okosan a Világkiállitás érdekében. Tartson az utazásom tovább, álljak meg nyugaton ott, ahol vannak barátaim, tartsak ismeretterjesztő tájékoztatást a magyar klubokban, erröl a világraszóló eseményröl. Ellátott ismeretterjesztő tájékoztatókkal. Szót fogadtam Karcag Ivánnak. Megálltam Bécsben, Dortmundban, Luxemburgban, Brüsszelben, sőt, még Izlandon is kihagytam egy járatot. Ott éjszakáztam, falunkból Izlandra elszármazott ismerősömnél. Az Egyesült Államokban, Kanadában ugyancsak ezt tettem."48 Az 1971-es Vadászati Világkiállításon Cséplő József trófeái közül is kerültek ki kiállításra. Trófeagyüjteményének néhány darabja (6. ábra) híven tükrözi szakértelmét, elkötelezettségét, természetszeretetét.

Öt év múlva - 2021-ben - újra hazánké lesz a megtisztelő feladat, hogy az 50 éves évfordulóra ismét megszervezze a Vadászati Világkiállítást.

\footnotetext{
43 Fekete István levelezéséböl - EPAepa.oszk.hu/.../EPA02451_ Erdeszettorteneti Kozlemenyek 60_2003 1

44 Valló L. 1986: 180

45 Valló L. 1986: 182. 183

46 Ifj. Fekete I. 2004: 269.
}

47 Tóth Sándor: Vadászati világkiállítás, Budapest, 1971 48 Tálosi I. 2001: 114. 115. 
Cséplő József Fekete István biztatását magáénak tudva folytatta az írást, és sorra jelentek meg könyvei. Műveiről az alábbi bibliográfiát Varga Róbert ny. könyvtárigazgató állította össze:

- Aranykard néhány koporsóval. Bp. 2000. Terra Print

- Hajnaltól késő estig: elbeszélések, vadásztörténetek. Bp. 2002. TerraPrint, 165 p. /Kvtár/

- Isten veled Pekedli. Bp. 1997. TerraPrint, 223. p.

- Kit sirat a lélekharang? Regény/ Cséplő József Budapest: Antikva, 1991. - 195 p. /Kvtár/

- Medvelesen Kanadában: Novellák/ Cséplő József - [2. bővített kiadás]. - [Budapest]: Antikva.

- Szőlőhegyi kalendárium. Hetven év a tőkék között. Bp. 1996. TerraPrint, 199 p.

- Vadászpuska és mázas kancsó: Novellák/ Cséplő József. - [Budapest]: Antikva. 1988. - 172 p.: ill. ; /Kvtár/

- A földért szólok. In: A Csokonai Asztaltársaság kisantológiája. Keszthely-Hévíz, 1989. Goldmark Károly Műv. Központ 65.p. Így éltem át (emlékezés).= Hévíz, 1993.4.17-20p

- Internálásom egy éve (emlékezés).= Hévíz, 1994. 4. 21-25.p.

A szülőföldhöz való ragaszkodás és a somogyi táj szeretete, ami megalapozta Cséplő József és Fekete István holtig tartó barátságát. Mindkettejük közös személyiségjegye a humánum, az őszinteség, a munka szeretete, a mély Istenhit és a természet csodáihoz való ragaszkodás, ami mind, jellemformáló tulajdonság egy ember számára. „Az utókor szerencséje, hogy mindketten belső késztetést éreztek arra, hogy gondolataikat papírra vessék és közkinccsé tegyék, és ezzel olyasmivel ajándékoztak meg bennünket, ami egyszerre gyönyörködtető élmény, az ismeretszerzés lehetősége, követendő emberi példák sokasága, valamint megszívlelendő gondolatok, és ami múlhatatlanul ott van minden természetszerető ember könyvespolcán és szívében." - idézve Sütő Zoltán gondolataiból. „Én azokat az alakokat rajzolgattam meg, akik már nincsenek, de voltak, és ha nem voltak: kellene, hogy legyenek!!! ... Szóval azt írtam, ami vagyok, ami lenni szeretnék. Én a levegőt, az erdőt, a mezőt, az embereket, születéseket, szerelmeket és elmúlásokat tisztának akarom látni és láttatni." - Írja saját magáról Fekete István, a somogyi születésű író.

Cséplő Józsefet megbecsülése és szeretete jeléül, Fonó Község Önkormányzati testülete 2011-ben 'Fonó község díszpolgárának' (7. ábra) választotta. Nem sokkal később, 2012. július 5-én helyezték örök nyugalomra a fonói temetöben. ${ }^{49}$

Gölle és Fonó „ma is” csak hét kilométer távolságra van egymástól, mint amikor a két szülőfalunak ekét, puskát és tollat forgató fiai barátságukat ápolták, amelynek emlékét őrizve ez a dolgozat született.

\section{Köszönetnyilvánítás}

A szerző hálásan köszöni a Cséplő Család, különösen Magyarné Cséplő Márta segítségét, támogatását, Prof. Dr. Sütő Zoltán, Dr. Ballay Attiláné, Dr. Ballay Attila, Fejes Éva és férjem, Lanszki József szívből jövő megtisztelő lektorálását.

49 Lanszkiné Széles G. 2013: 207.

\section{Irodalom}

BÉKÉs S. 2009.: Ráterült a természetre ... Magyar Vadászlap 2009. szeptember

CsÉpLő J. 2011: Hajnaltól késő estig. Elbeszélések, vadásztörténetek.

Hodıcs GY. Emlékiratai. Kézirat.

KIss E. 1935: Alsó-Dunántúl mezőgazdasága. Országos mezőgazdasági címtár. I országos rész. Kaposvár Alsó-Dunántúli Mezögazdasági Kamara.

LANSZKINÉ SZÉLES G. 2013: Fonó története és néprajza Fonó Községi Önkormányzat

LESKó L. 1997: Kalendáriummal a szölöhegyen. Szabad Föld 1997. április 8. 14. szám.
IFJ. FEKETE I. 2004: Fekete István az Édesapám volt... Móra

SÁNTA G. 2005: Fekete István tanulmányok 2. 221

Sánta G. 2014: Fekete István nyomában Rendhagyó életrajz. Móra Könyvkiadó, Budapest.

SOMOGYI HíRLAP 2000. november 28. XI. évf. 278. szám.

TÁLOSI I. 2001: Ötven vadász emlékeiböl. Terra Print.

TóтH S. 1971: Vadászati világkiállítás, Budapest.

VALLó L. 1986: emlékké válok magam is... Fekete István élete. Móra Könyvkiadó, Budapest.

http://www.fekete-bp10.sulinet.hu/

MNL SML GFI 1909. augusztus. Fekete Árpád levele. 


\section{FEKETE ISTVÁN}

BUDAPEST II.

TAROGATÓ ÚT 77

$$
\text { C s é p I ő J ó z s e } 1 \text { urnak, }
$$

Fonó. 16.

Kedves Barátom!

Ievele végtelenuil jól esett,mert benne van minden amit szeretek. Mult van benne és szelid mámor, emlékek vannak benne és hazai táj, emlékezés van benne a és hivogatás vallahova, ahova a mult ezer szála füz és nagyon nehéz kimondani,hogy mégsem mehetek.

Nehéz ezt kimondani, leirni és megtagadni valamit, amit minden idegszálával kiván az ember, de mégisem lehet felmenni a sóvárgás és a mult szőllőhegyére,mert egészségi álllapotom nem enged meg semmi könnyelmuiséget,már pedig, ha már ott lennék, ki akadáljozhatna meg abban hogy ujra huszonöt éêysnek ne érłezzem magam?

Egy nagyon sulyos vesemitét után vagyok, amire ráadásul még gyomorvérzést is kaptam s ezért nem mehetek sehova, nem fogadok el egyetlen meghivást,mintha talán éppen azok az elmult szép napok és ifjui hejehuja boszulnák meg magukat, amelyek ott estek meg a Sárkány hegyen a taszári és homoki dombokon, ahol nyakló nélkiul itttuk a zöld szilvánit és a rákói vöröst vegyest...

De levele mégis mélységes örömet szerzett nekem, mert gondolatban ott va.gjok és ott leszek, ha majd csendil a pohár, száll a dal és a mámor szeretettel hálózza be a szemeket.

Meghivását ugy őrzöm meg,mint az elmult ifjuságba szólitó legszebb emberi megnyilatkozást és, ha testileg nem is, de lélekben a kis fehét szobában szeretettel és egész szivvel ott leszek!

Igaz barátsággal köszönti öreg hive:

Budapest, 1963. november 13. 


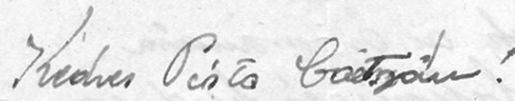

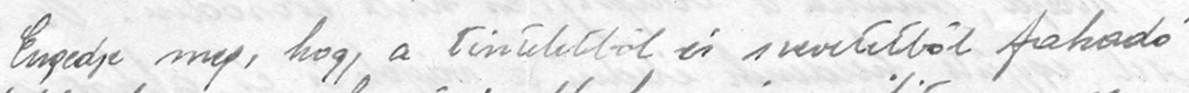

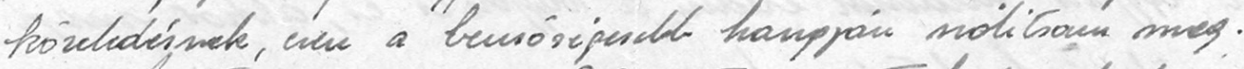

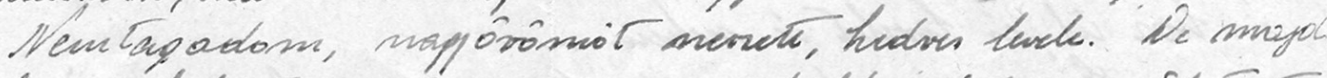

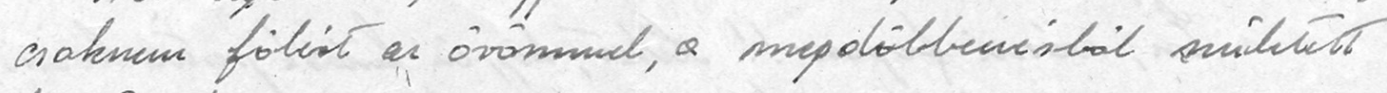
perevinig.

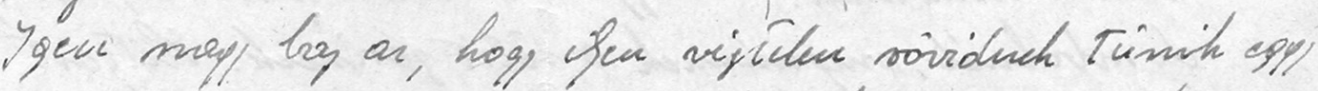

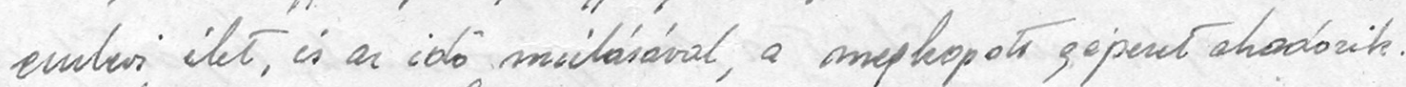

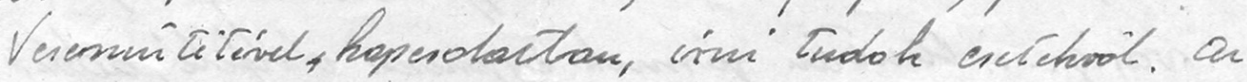

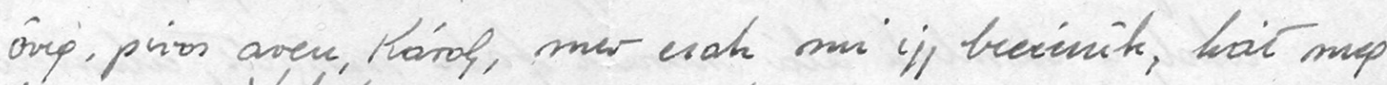

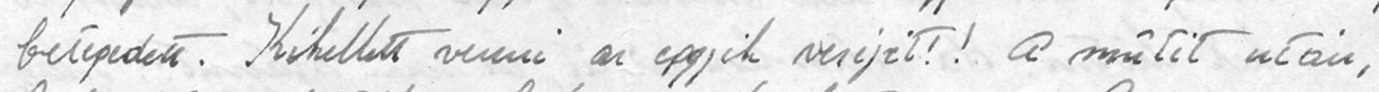

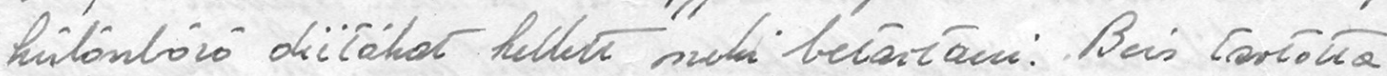

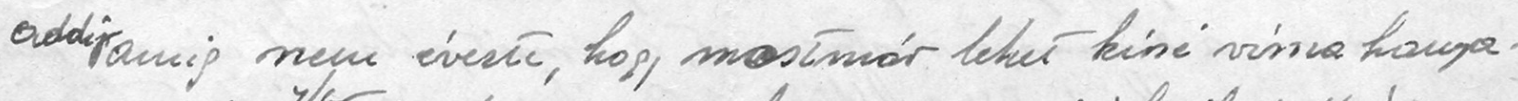

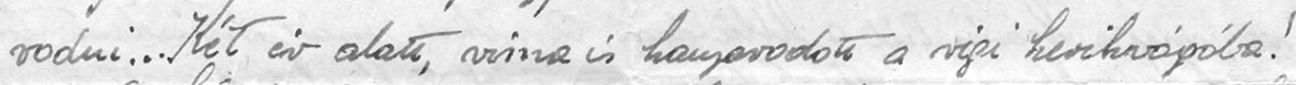

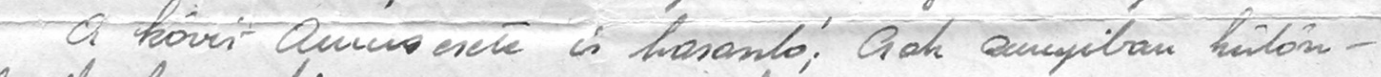

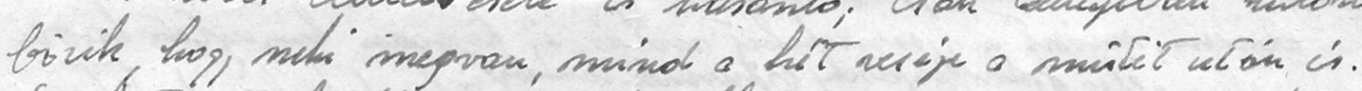

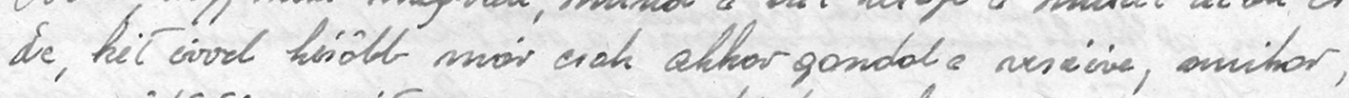

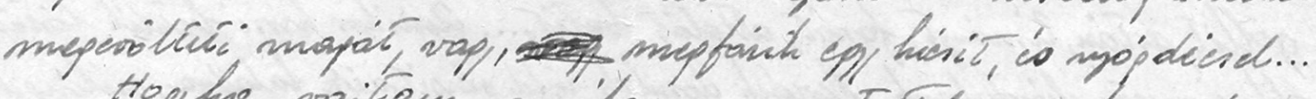
Hophe, vayiam mitacia, nevtuted mijogmain mina

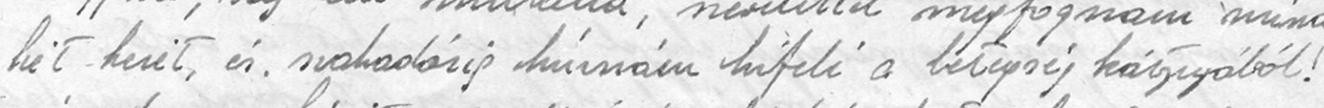

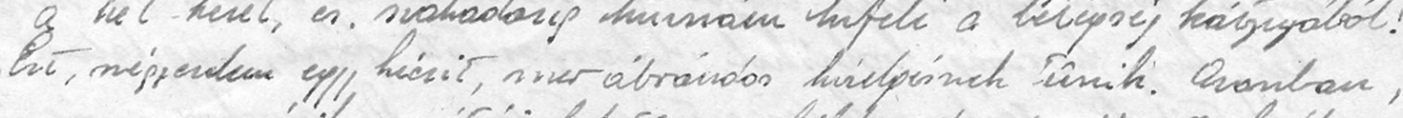

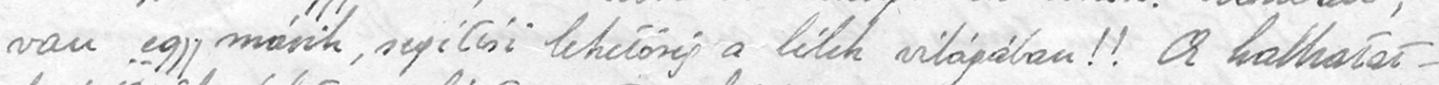

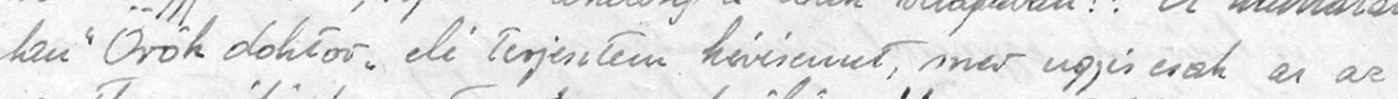

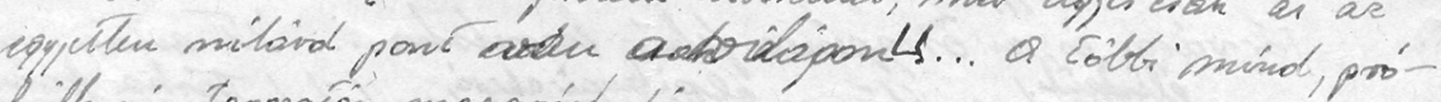
bathozár, Tapopacios, maparánhodai...

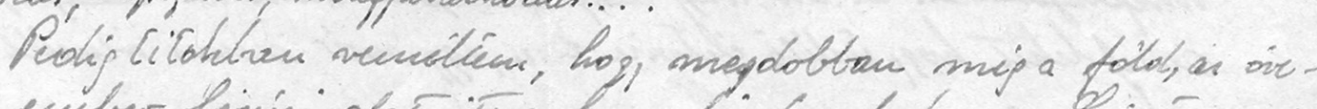

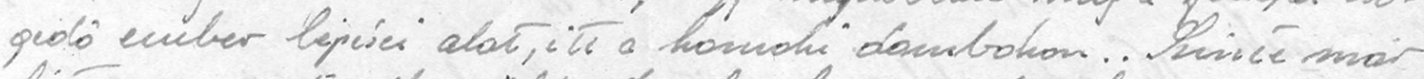

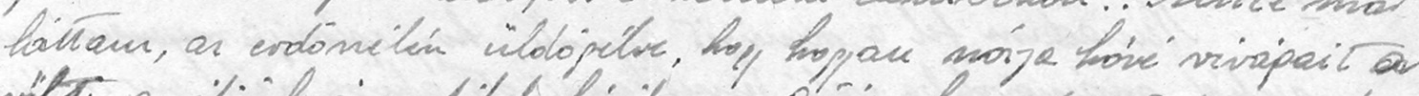

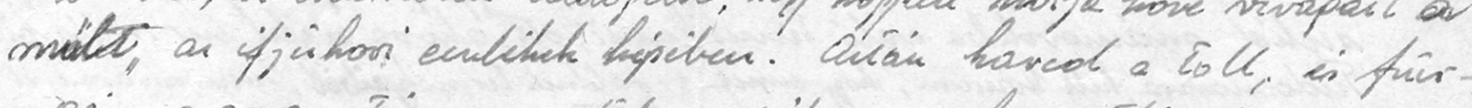

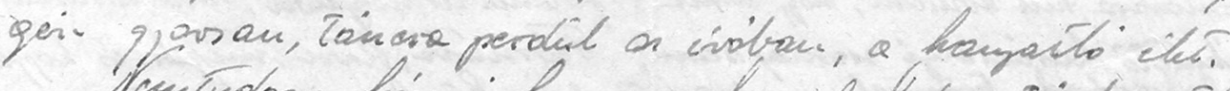

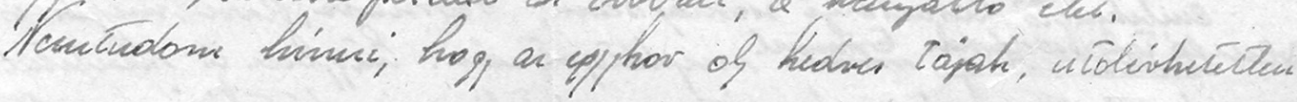


meseomoiggá legjench as Ón mainaía.

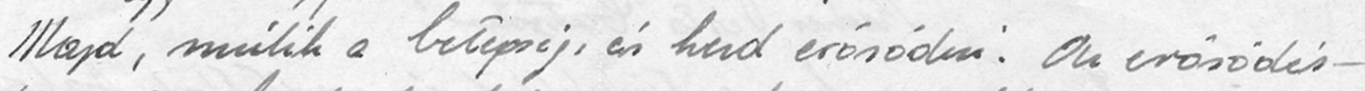

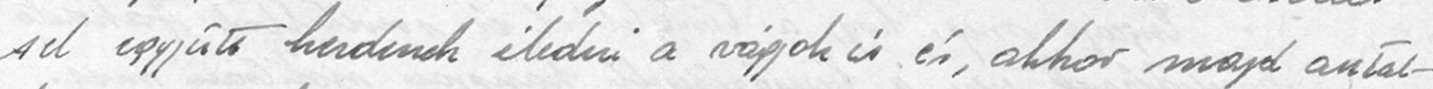

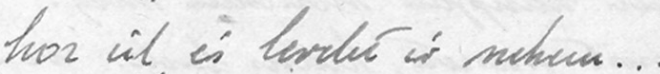

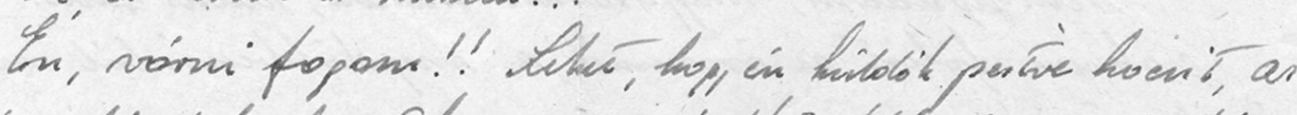

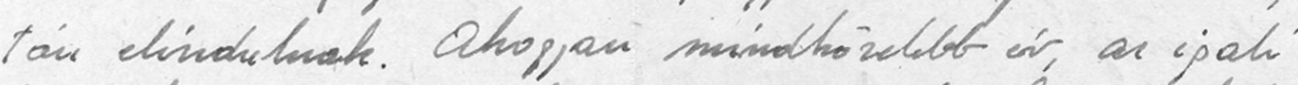

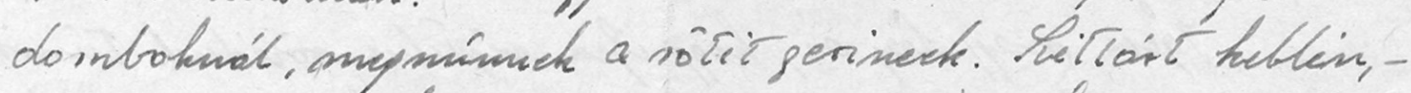

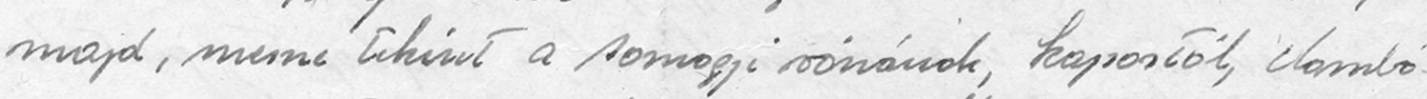

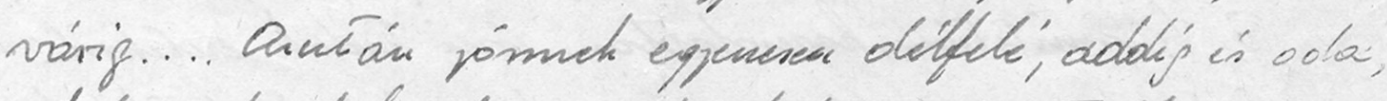
atiol, a damboh alá monute falu mojote, alunodo evdo-

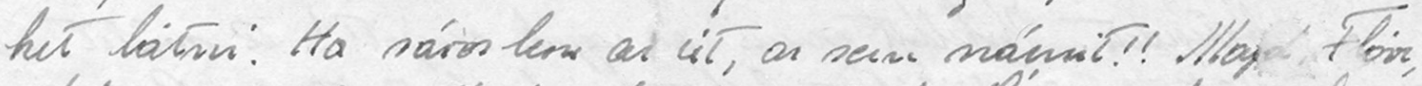

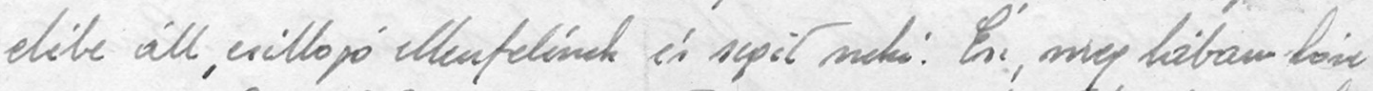

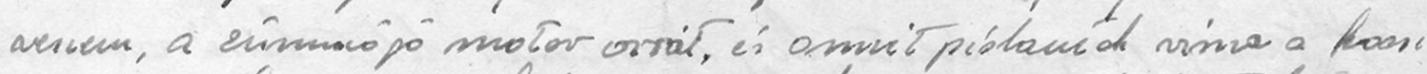

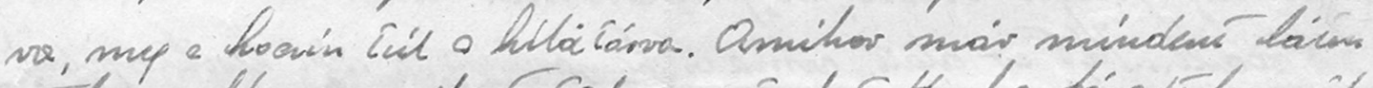

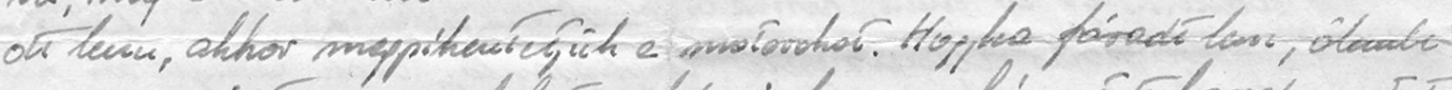

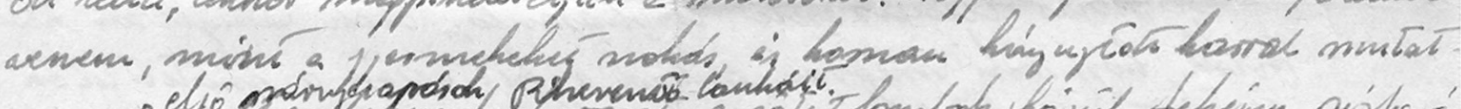

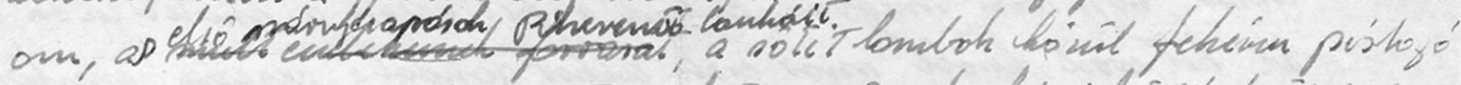

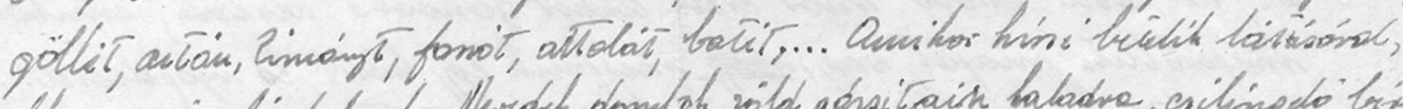

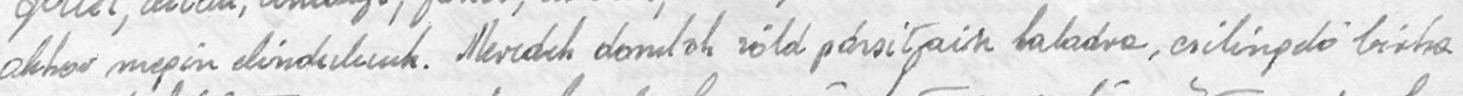

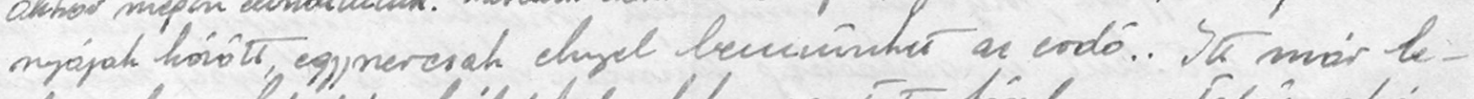

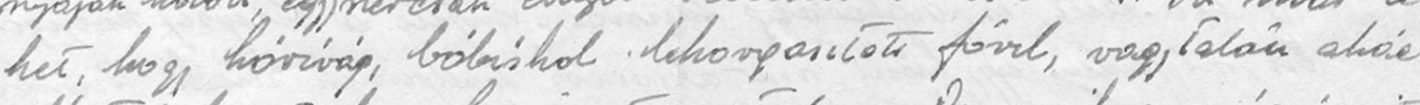

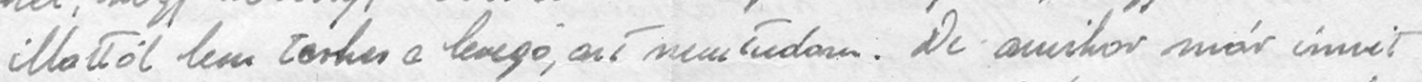

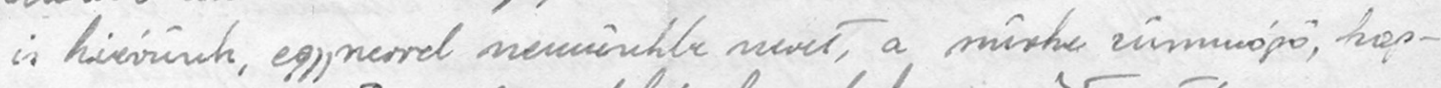

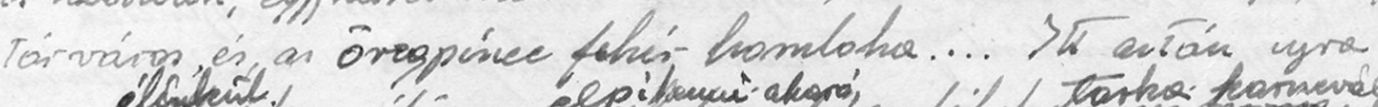

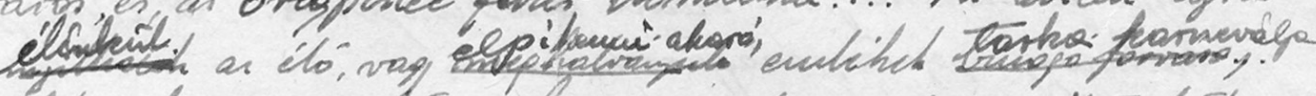

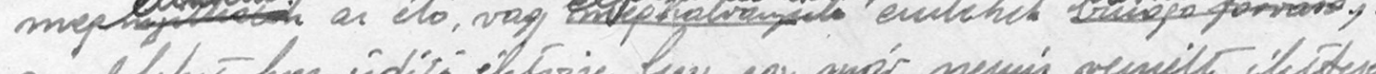

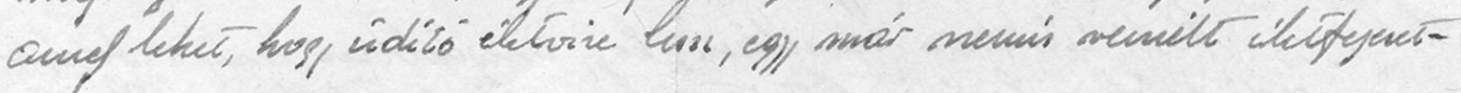
net...

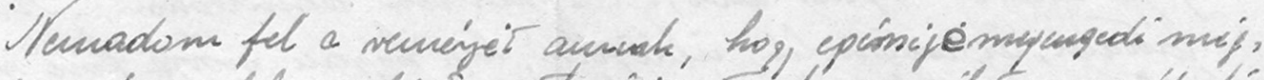

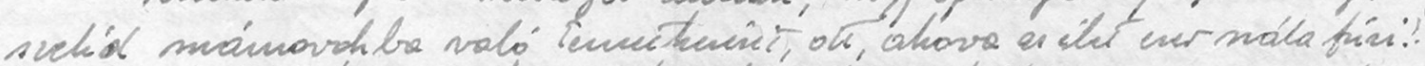

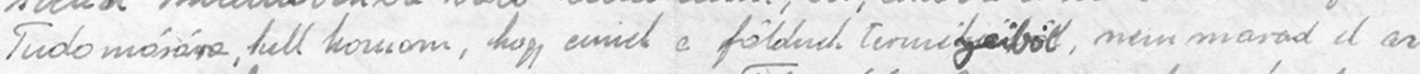

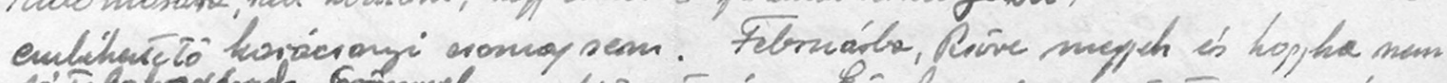

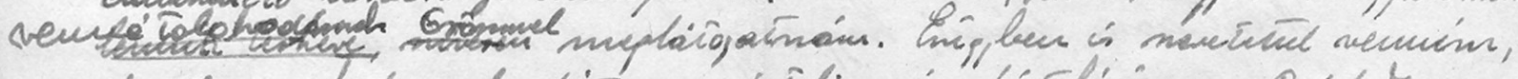

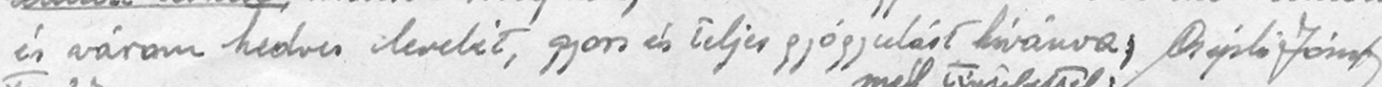




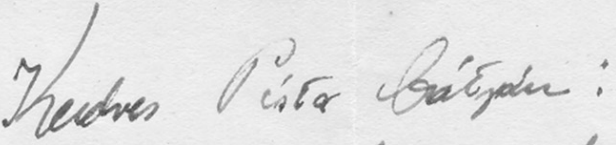

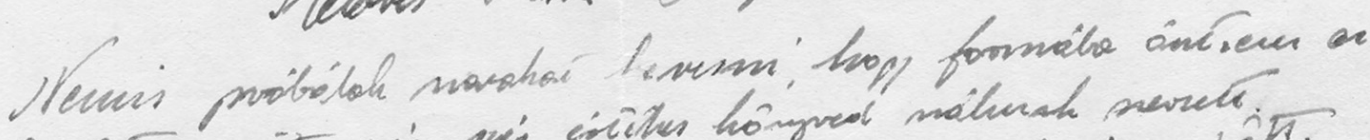

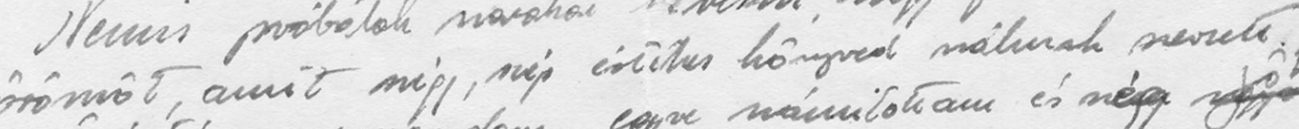

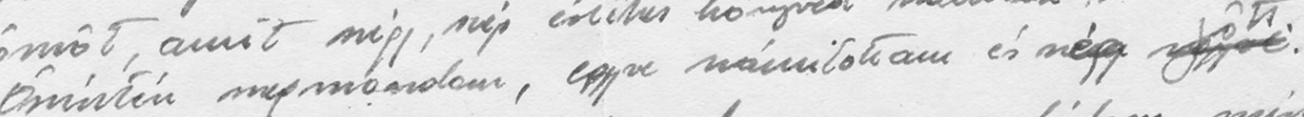

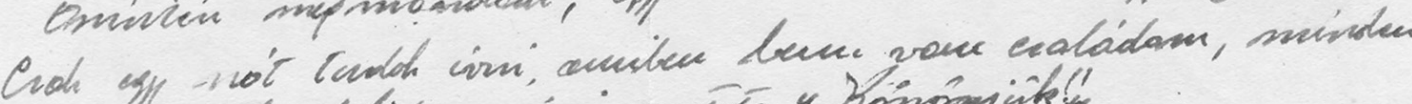

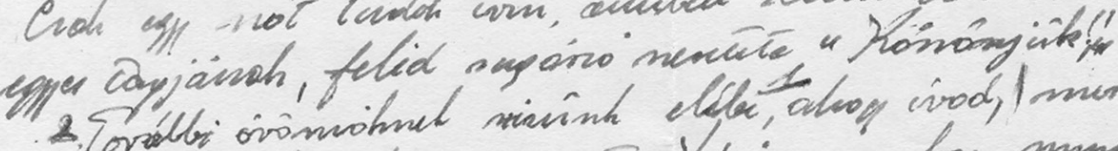

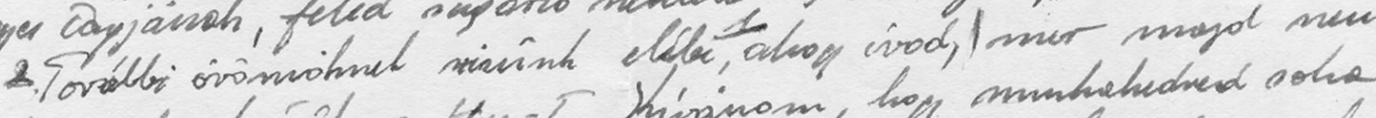

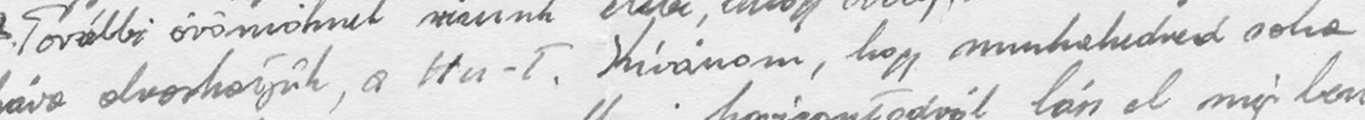

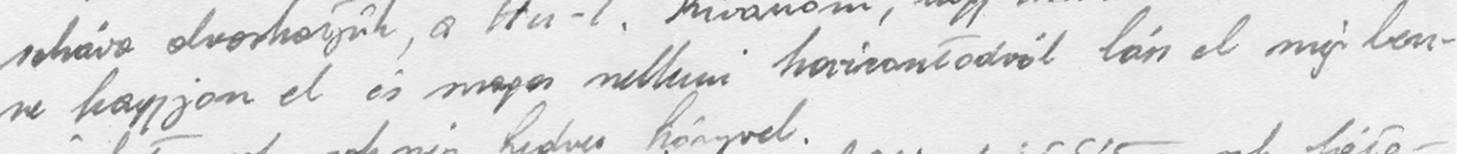

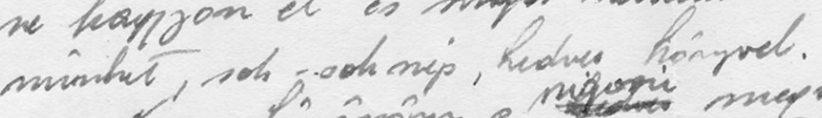

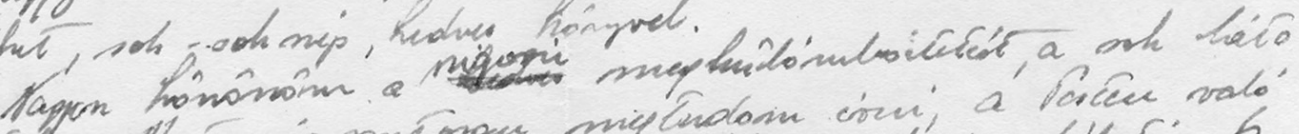

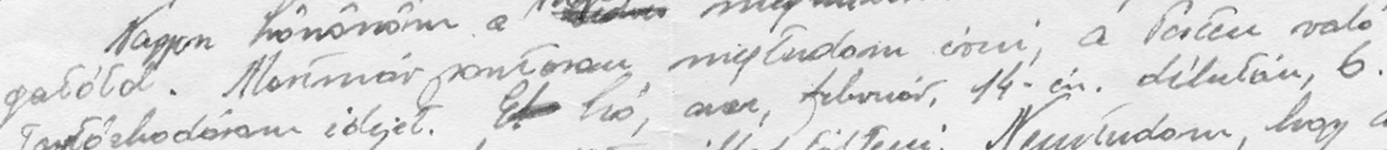

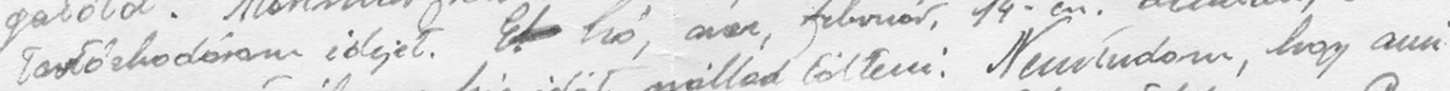

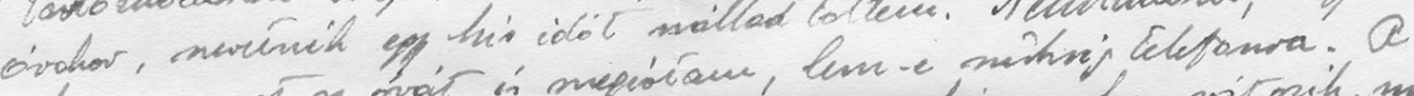

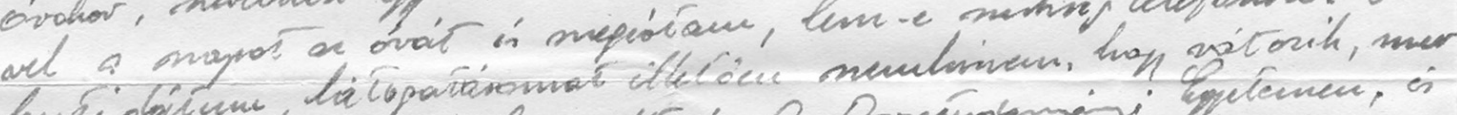

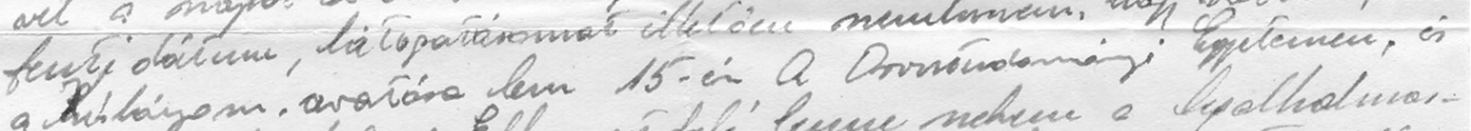

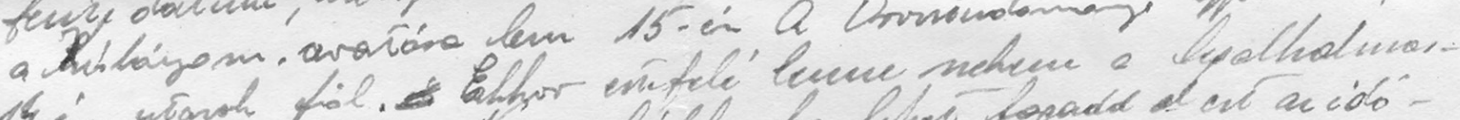

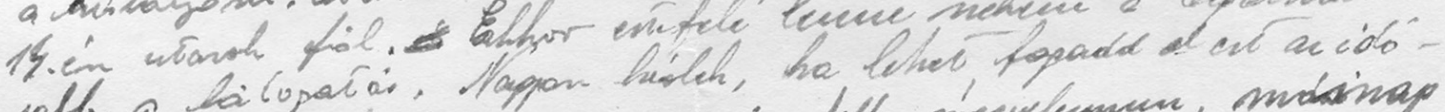

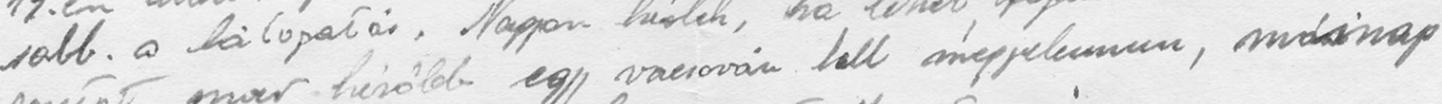

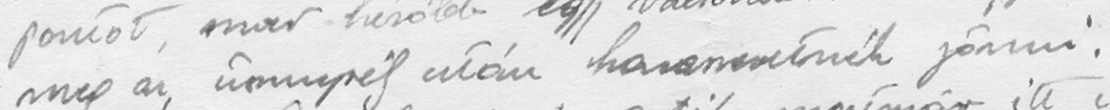

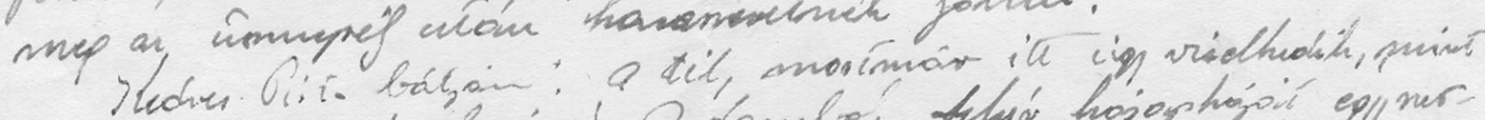

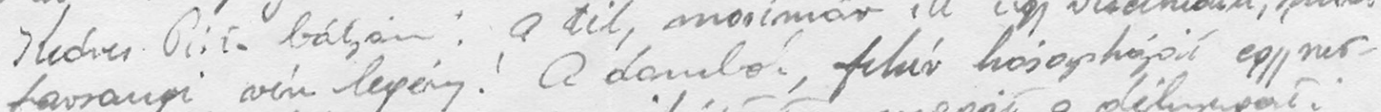
em, favraugr vin lepeng.

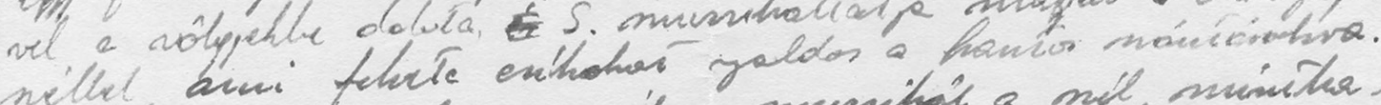

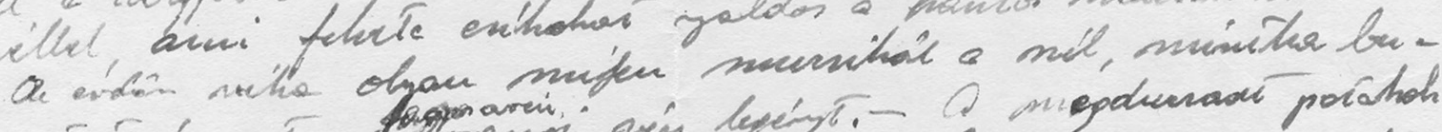

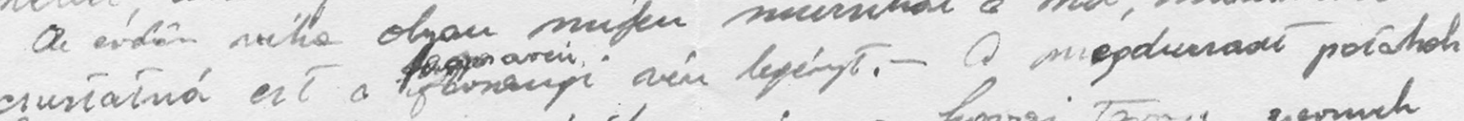

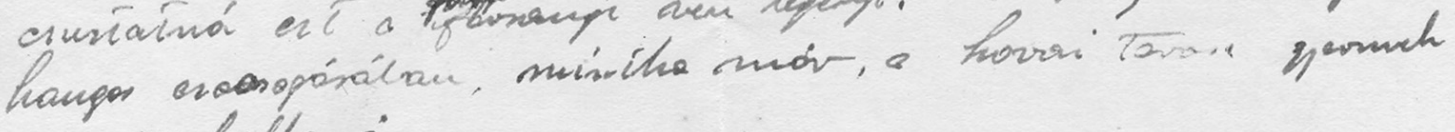
invis hallamain.

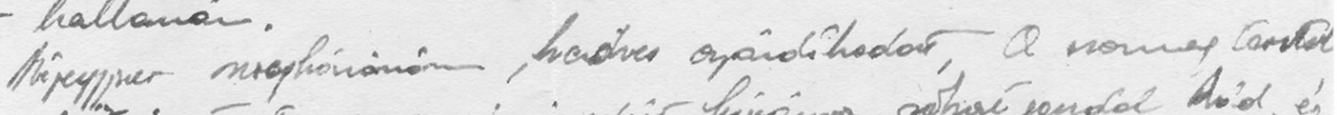

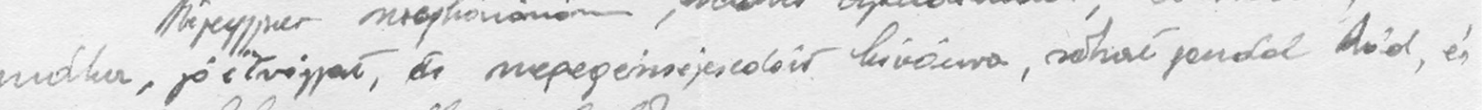

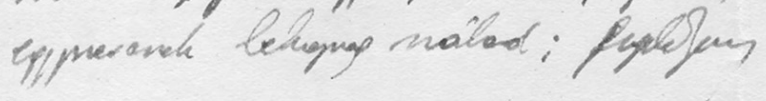

$$
\text { a. } Y
$$




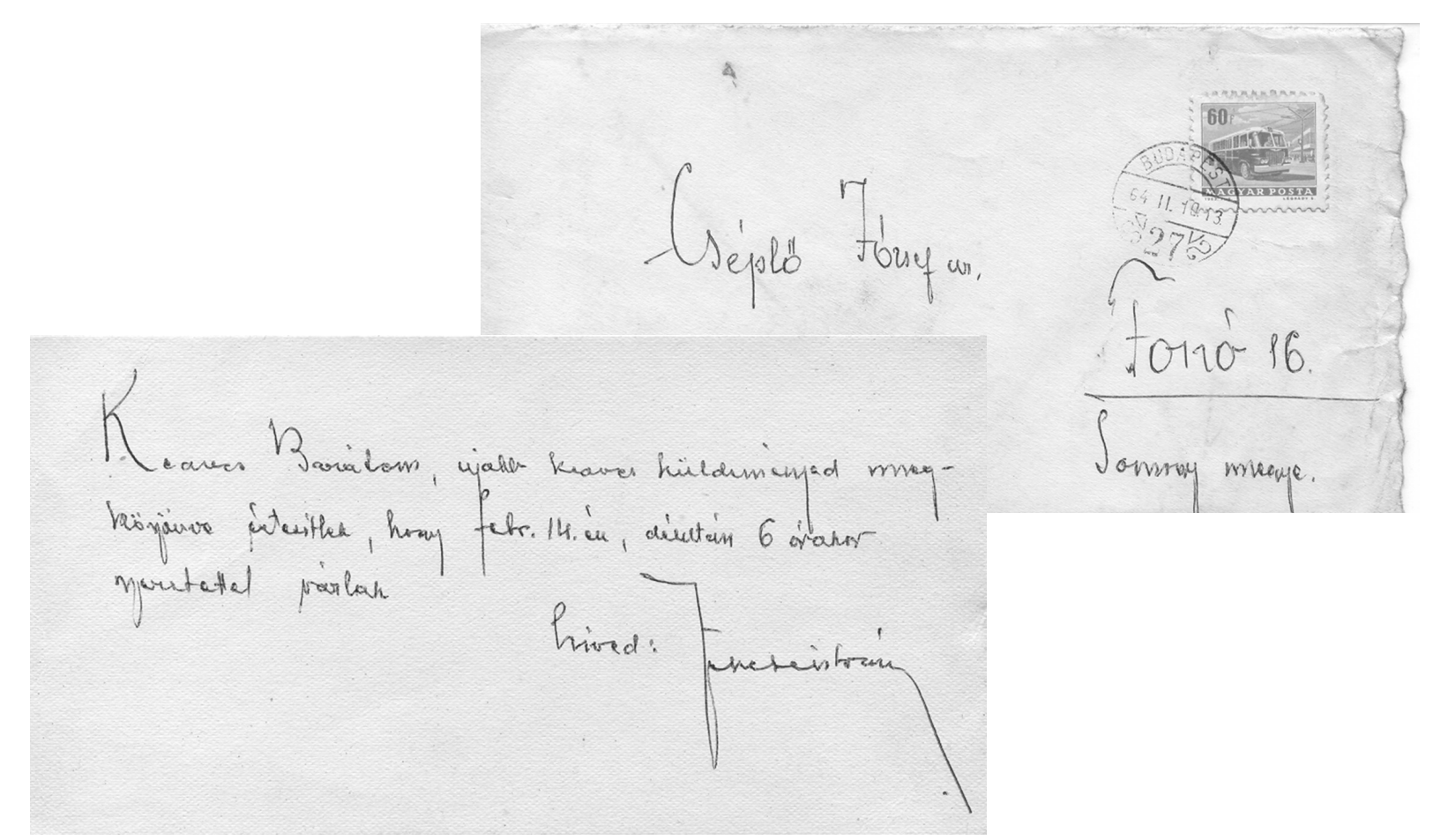

4. levél. Fekete István levele Cséplő Józsefnek (1964. február)

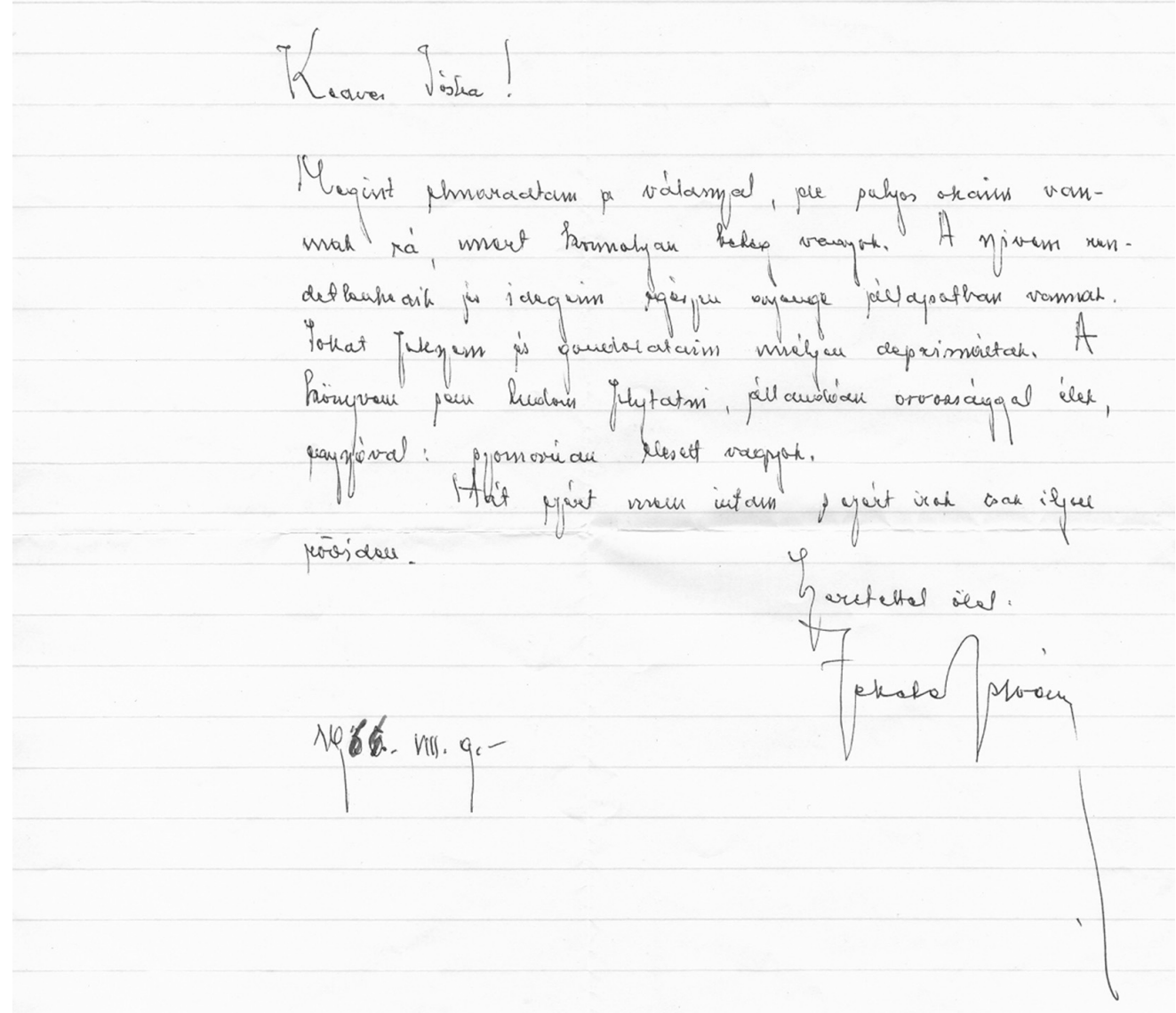

5. levél. Fekete István levele Cséplő Józsefnek (1964. augusztus 9.) 


\section{Dropáa gó Pábia baitgaim.}

Fajolalmas medolobucibad vetten, roivid

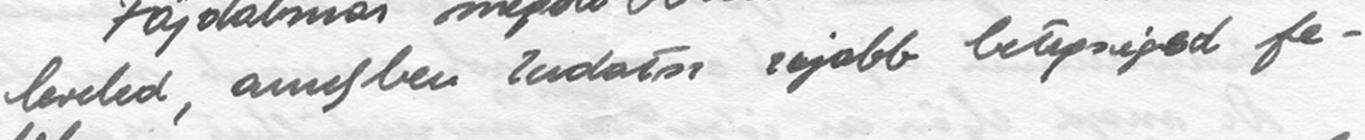
liol.

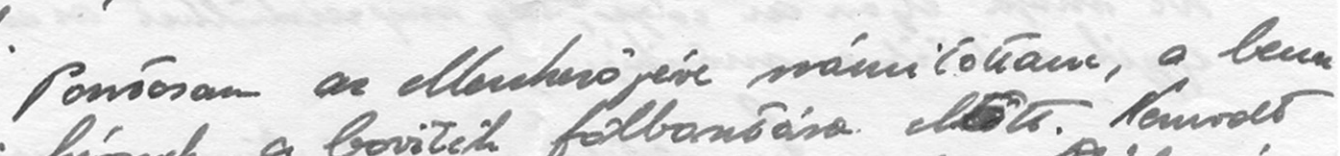

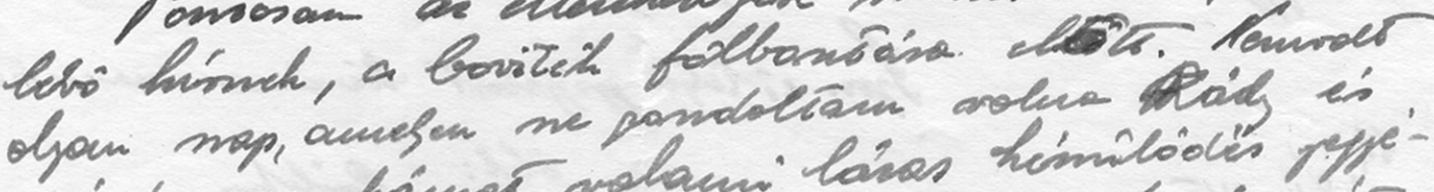
minden mushássat, volaui láras himilioiés pepé-

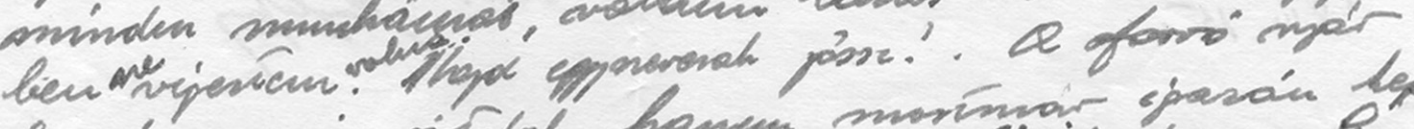

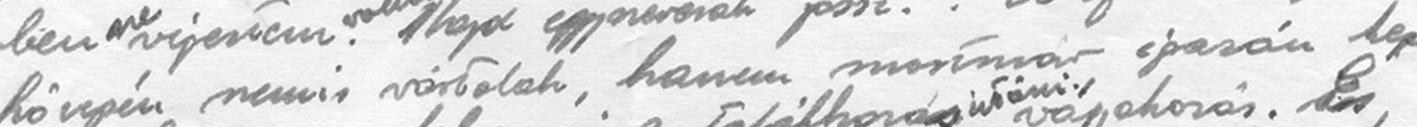

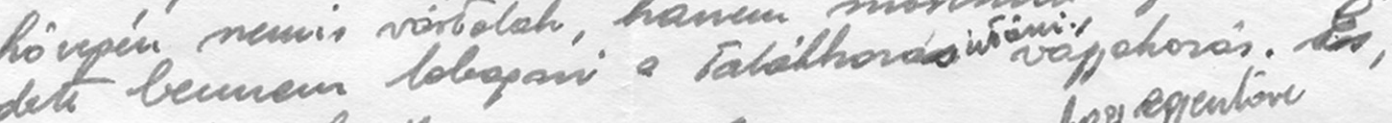
der hos rention

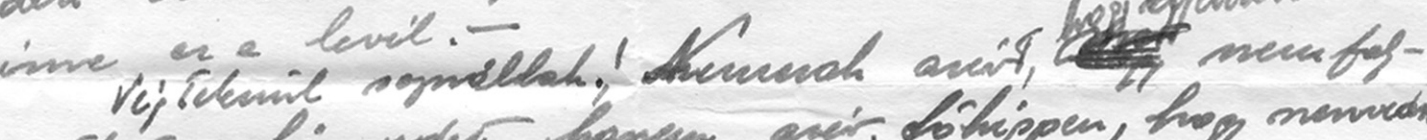

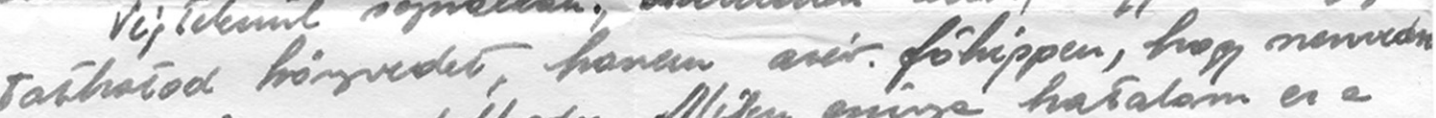
es gyotividure pondolhodus. Nlifen exinge haratom es a beceprign. -

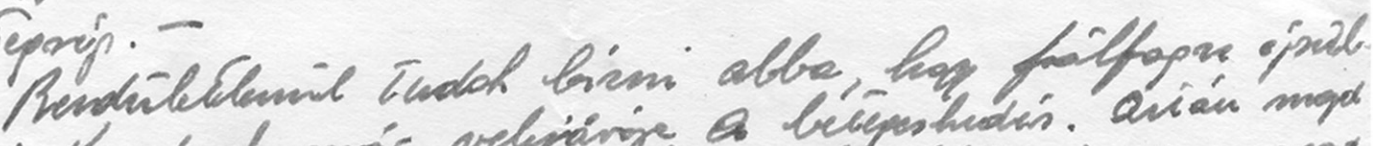

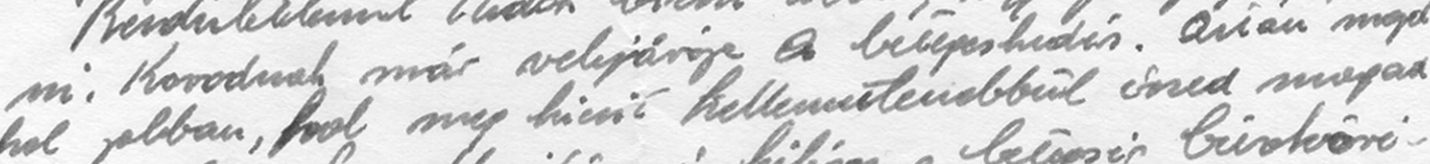

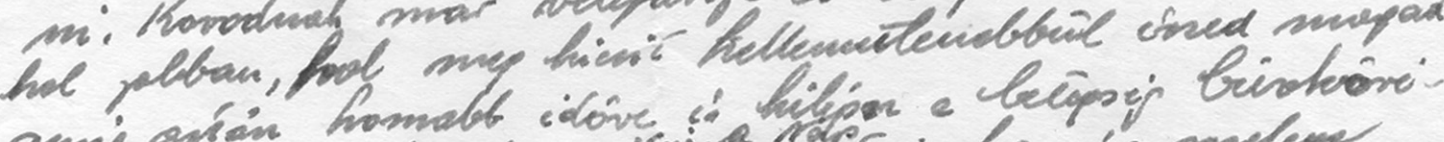

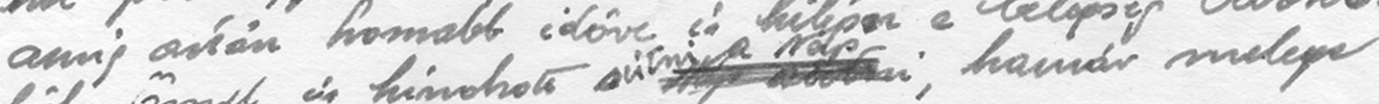
bid. armet is hamohou

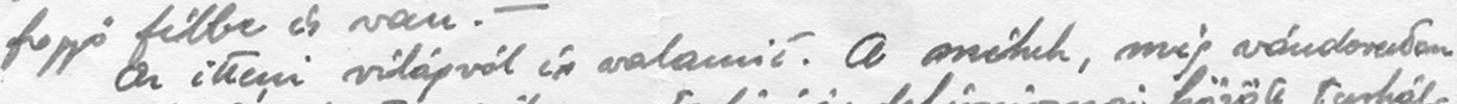

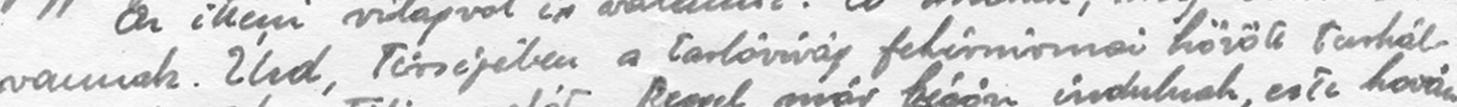

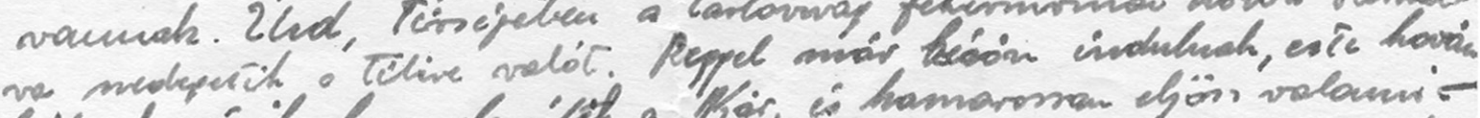

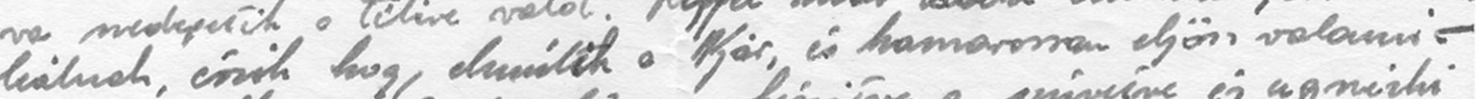

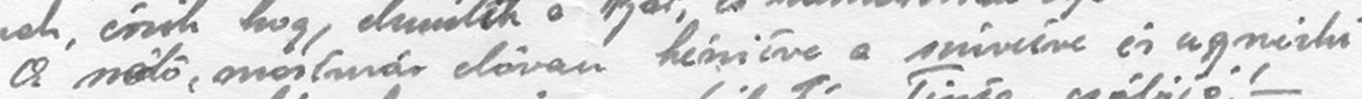

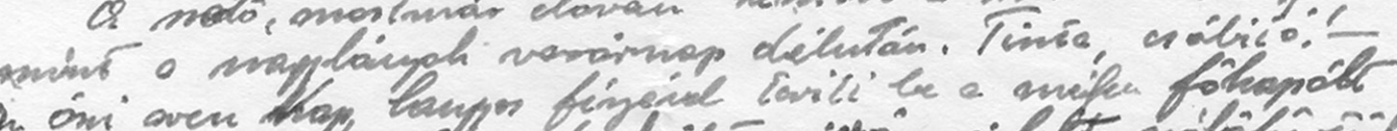

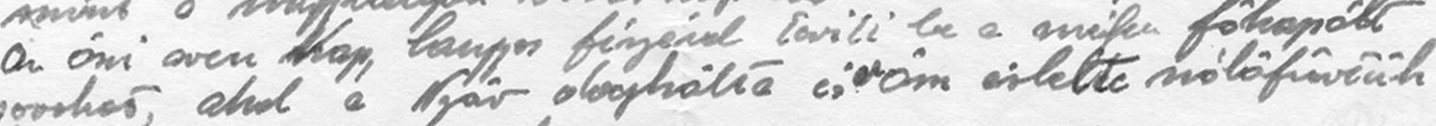

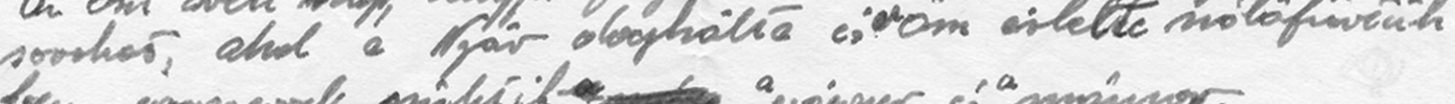

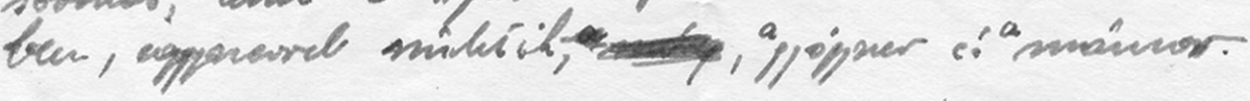




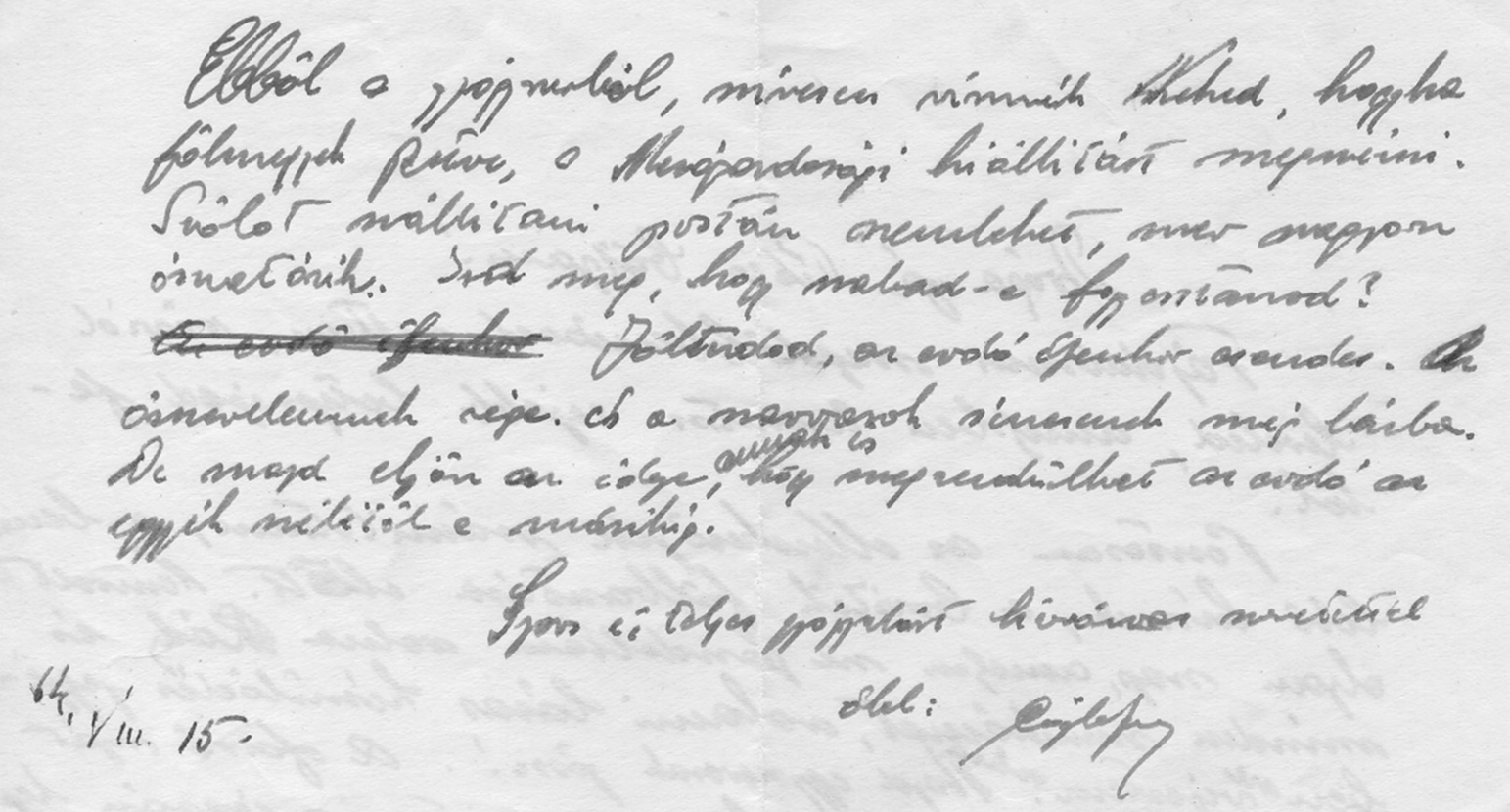




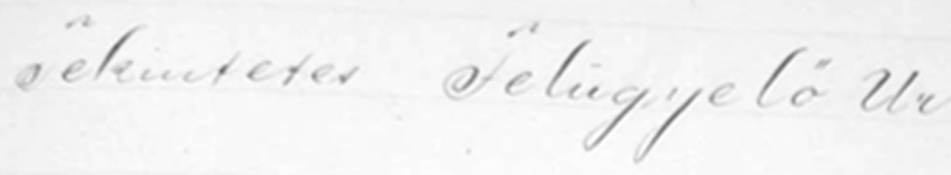

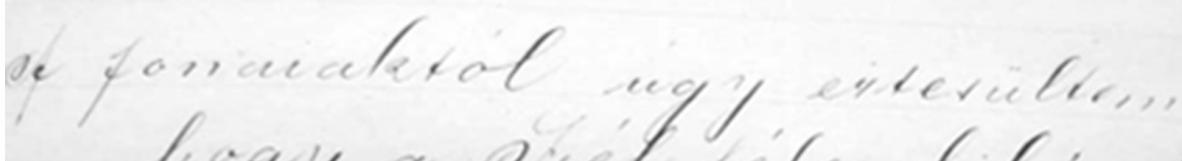

liagil a exél file liteind eviate arotancele a telieines redexterlictöle be a licle areleintererrégede of riggedily,

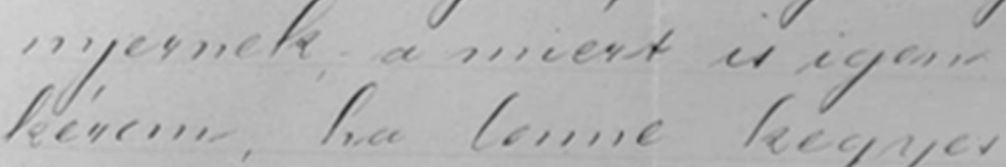

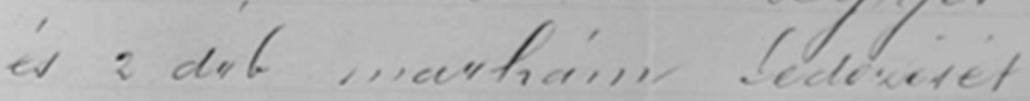

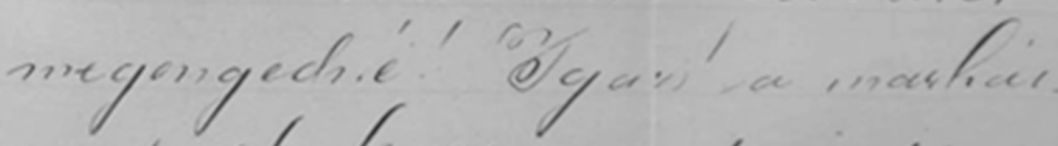
nat clateanos, aden de a

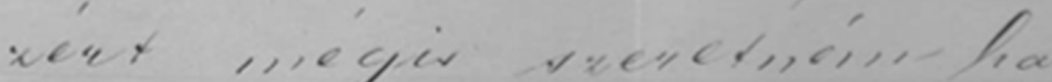

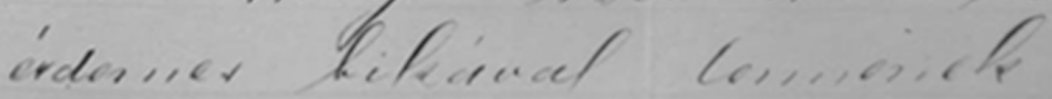
fejedone

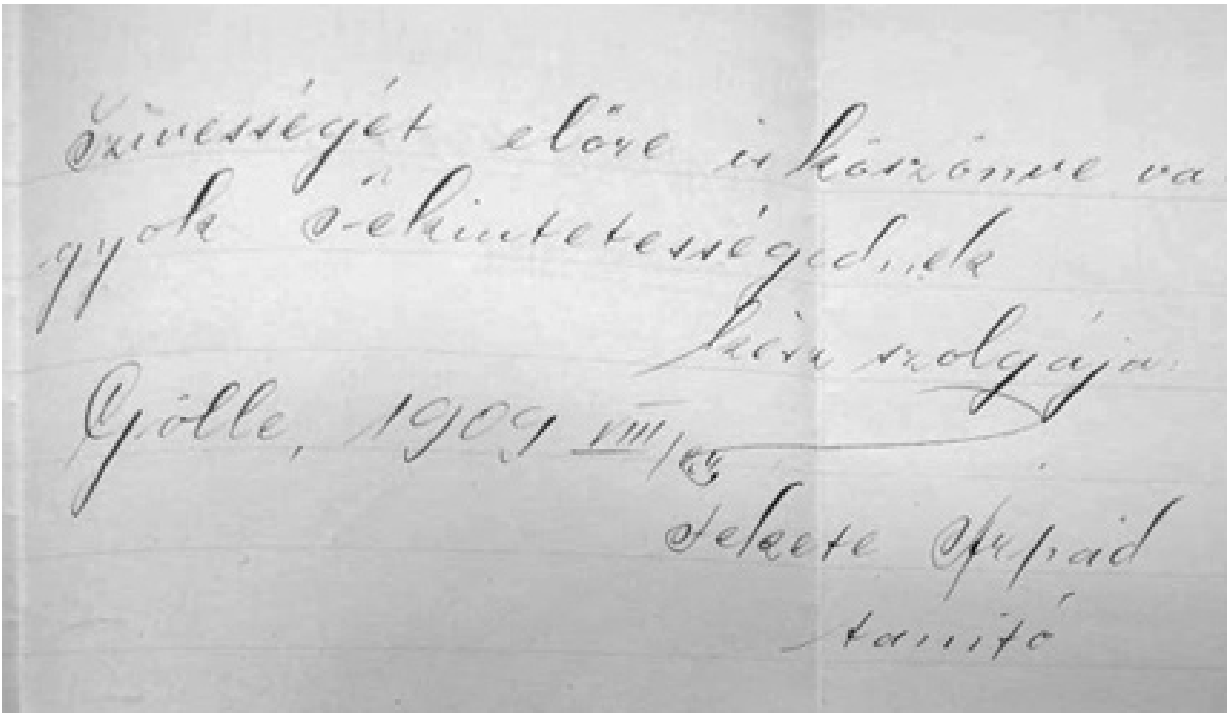

7. levél. Fekete Árpád levele a Gazdasági Felügyelönek (Gölle, 1909. augusztus) 


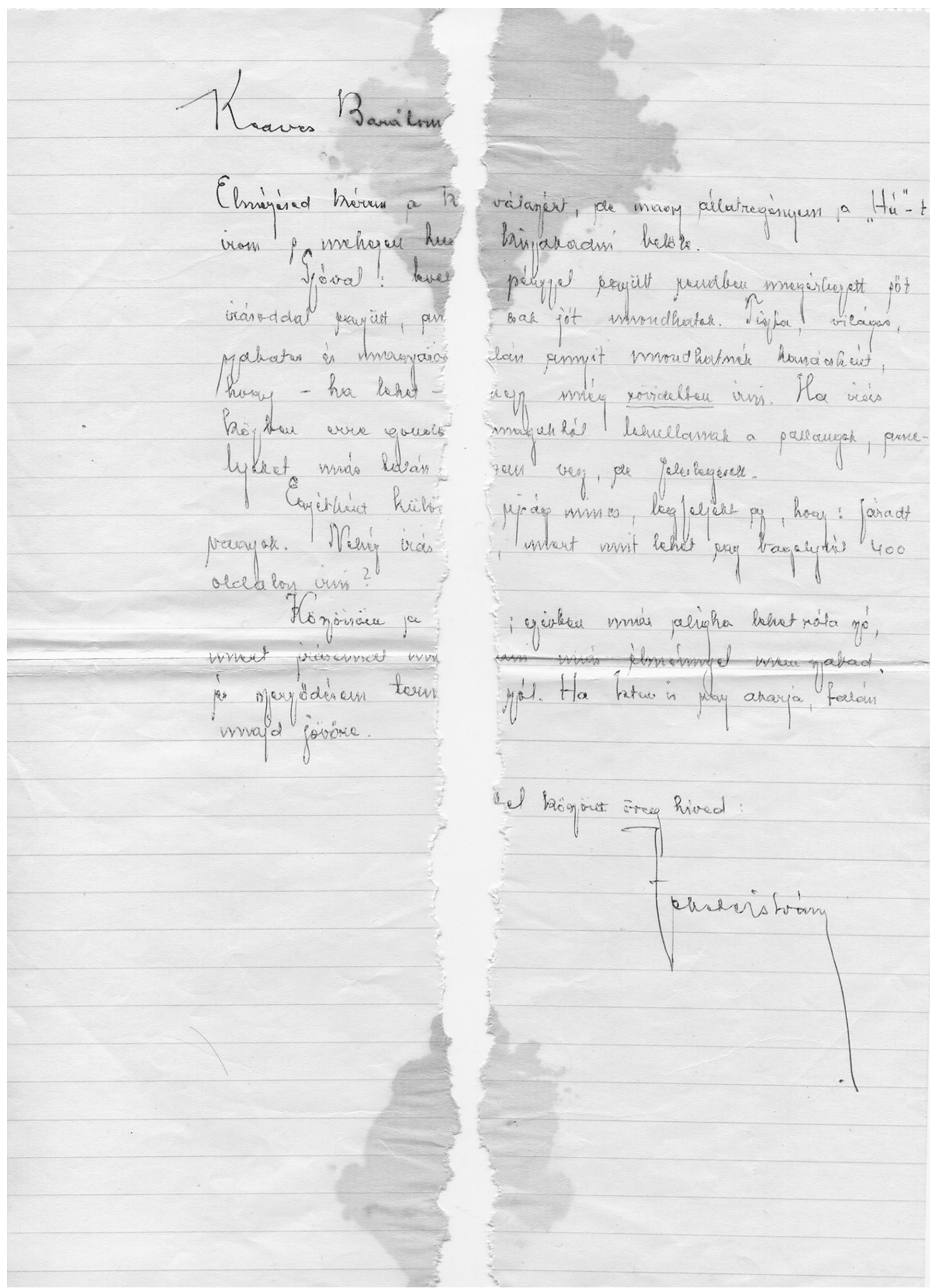




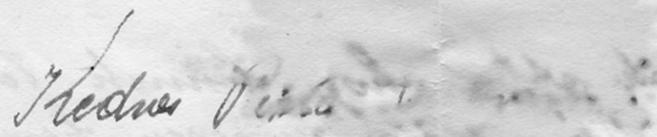

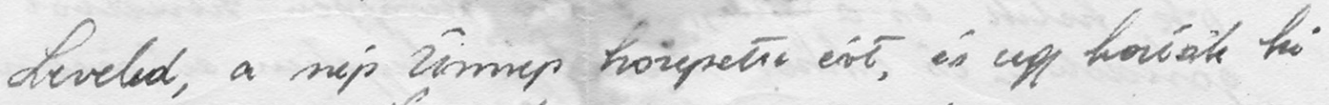

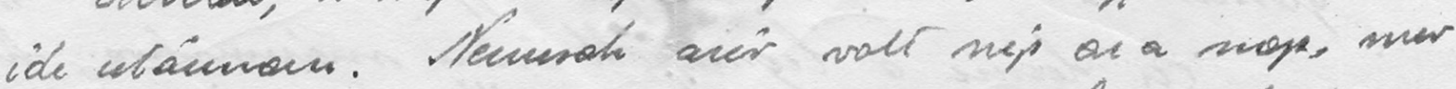

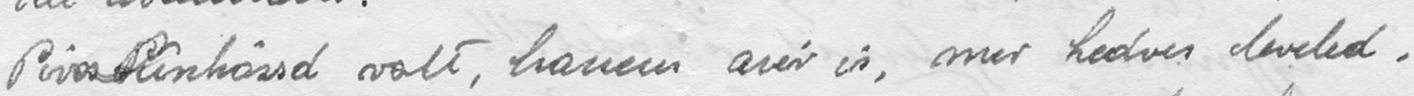

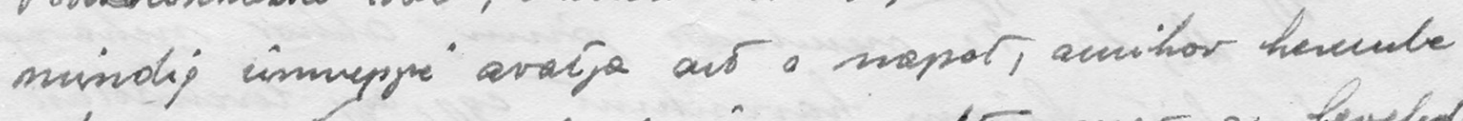

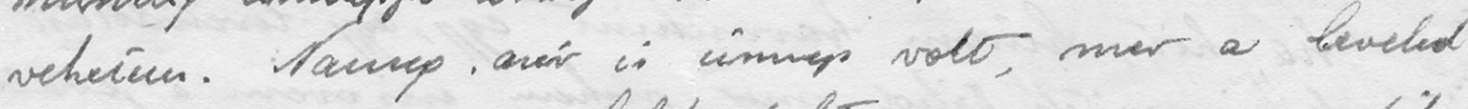

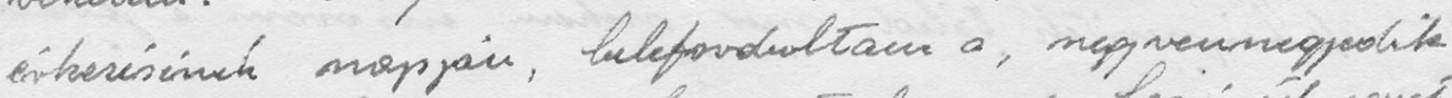

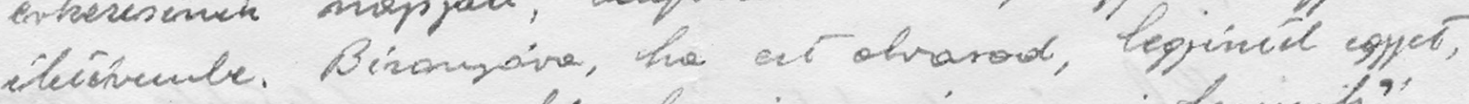
is ari monoloo', "Shy, he ex mej aungi devivats?.

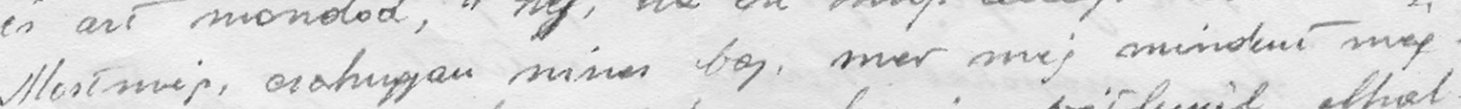

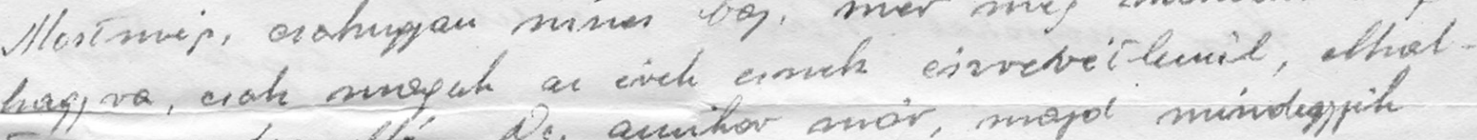

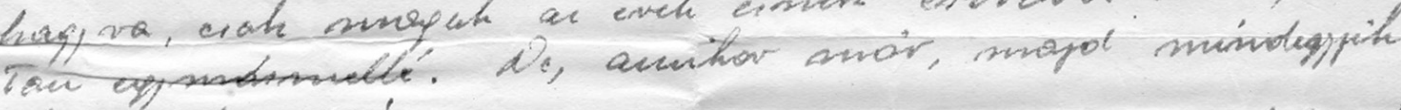

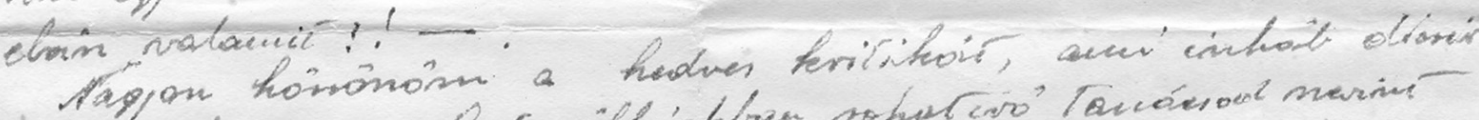

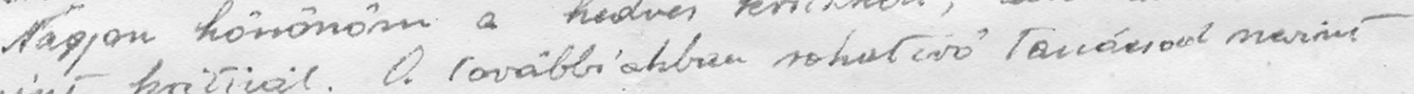
pinot el.

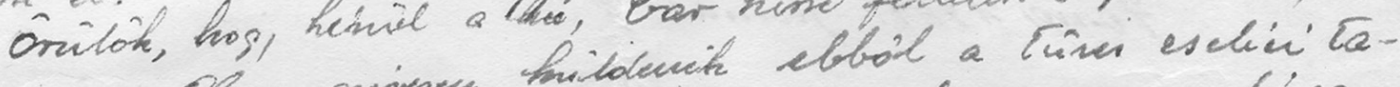

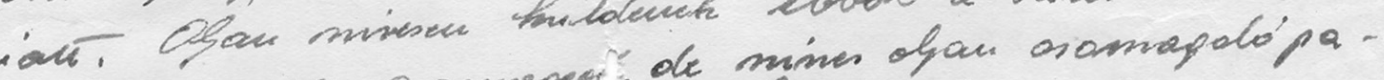

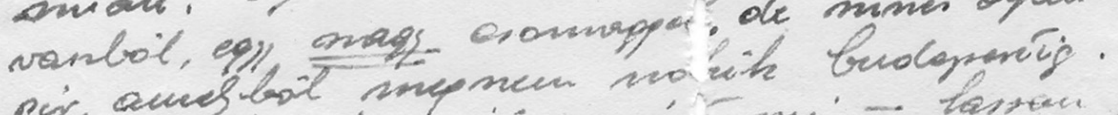

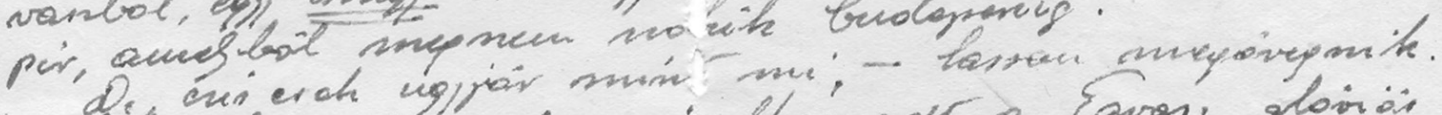

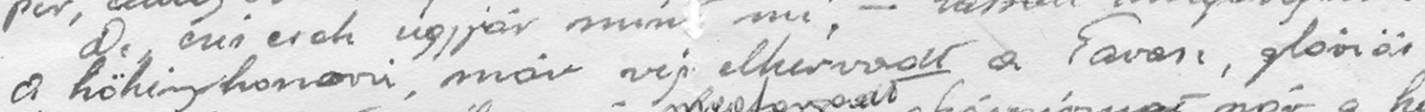

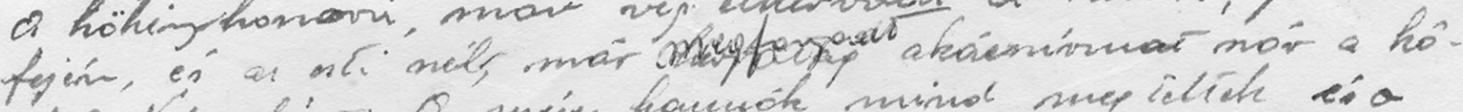

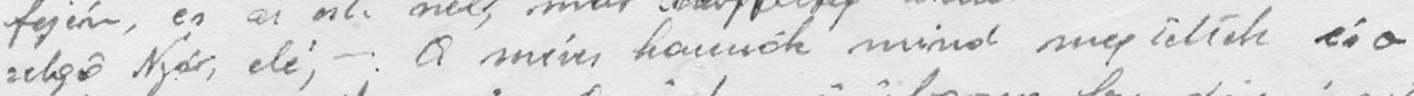

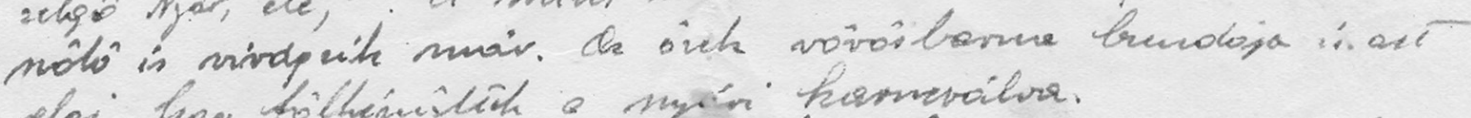

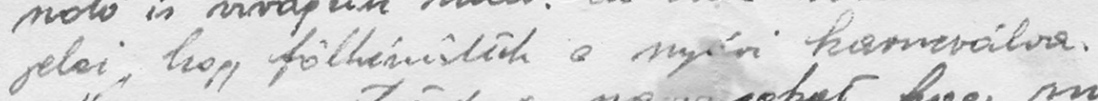

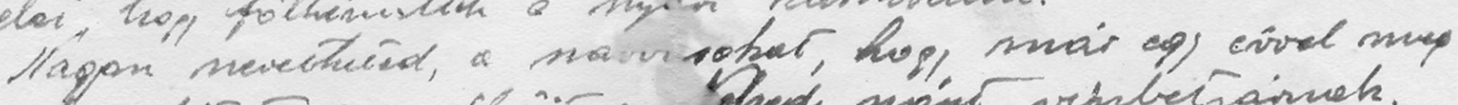

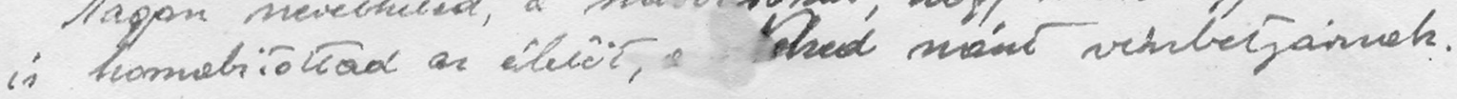


Kedves Barátom!

Meleghangu kedves leveled nagyon köszönöm. Sajnos én a tél szépségeiből kevesebbet látok,mint valamikor régen, de azért a tél mégiscsak tél a szellemi elmélyuilésnek s csendes elgondolások nak ideje. En ezeket a szellemi kirándulásokat arra. használom fel, hogy irom nagy állatregényem a Hu-t,amivel szeretnék a nyárra készenlenni,hogy gondtalanul nyaralhassak vagy a szigligeti alkotóházban,vagy a Kisbalatonban.

Levelemmel egyidejüleg adtam fel a csomatot a könyvek kel kiegészitve,amiket szeretettel kildöttem.

Ha Pesten jársz és megakarsz látogatni,előzőleg feltétlen hivj fel telefonon,mert enélkiil nálunk nem nyilik ajtó senkinek. Telefonon azután megbeszéljük kijöveteled pontos idejét.Tele fonom száma 164-496. -

Erre az óvintézkedésre azért van szükség,mert egyébként az alkalmatlan látogatóktól nem lenne nyugtom és én semmiféle kiváncsi tolakodásnak nem alok rendelkezésére. Egyébként is đolgozom s ilyenkor - eltekintve a tiéohez hasonló esetektól - soha nem állok senkinek rendelkezésére. Ezért nem megyek sehova,nem fogadok el semmiféle meghivást,amit egészségi kondicióm megőruése is szikségessé tesz,hiszen éppen csak,hogy nem maradtam ott a muitőasztalon. Karácsonyi keđves megemlékezéseđismételten megköszönve remélem a csomagot rendben megkapod.

SzivböI köszönt:



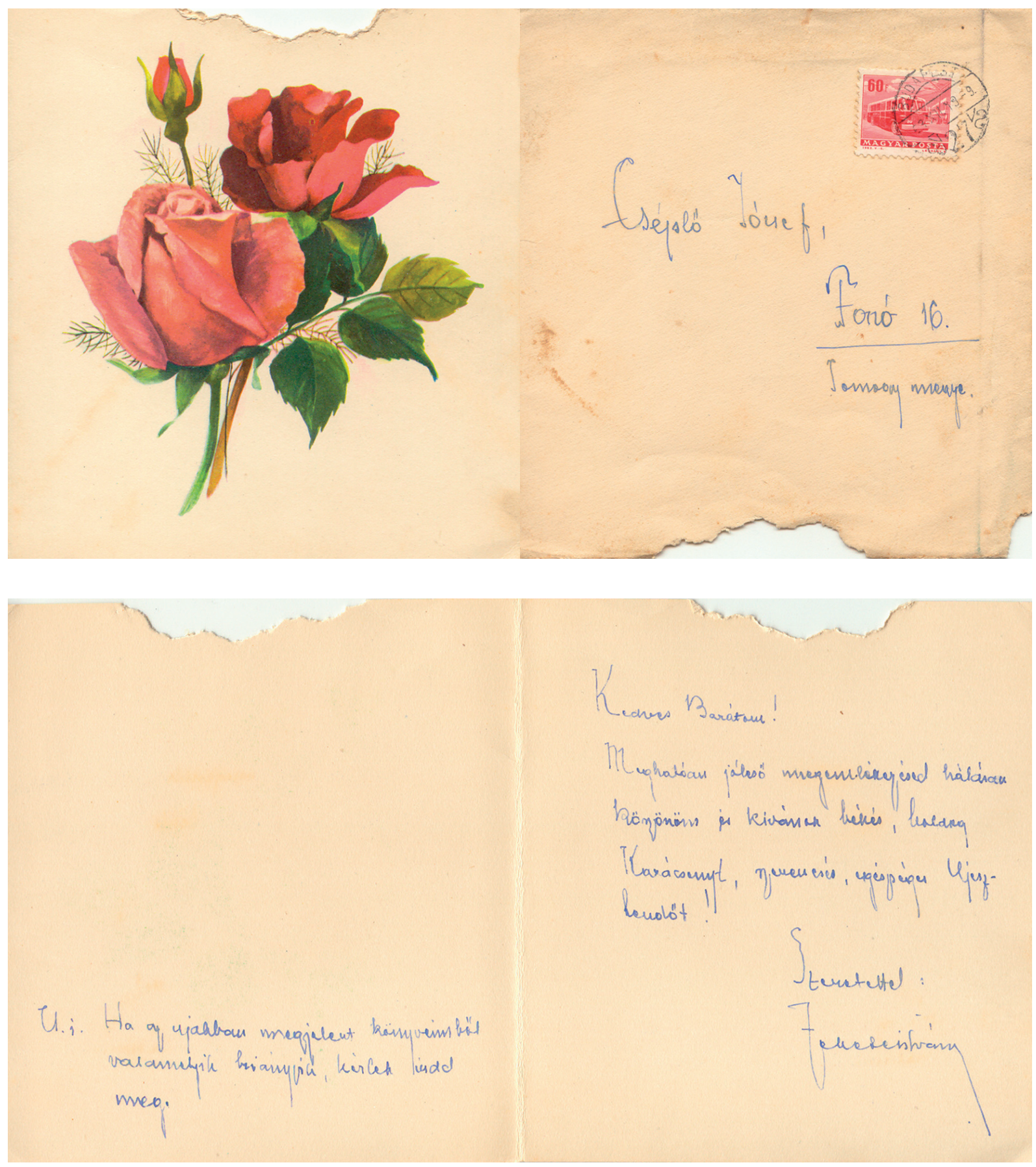

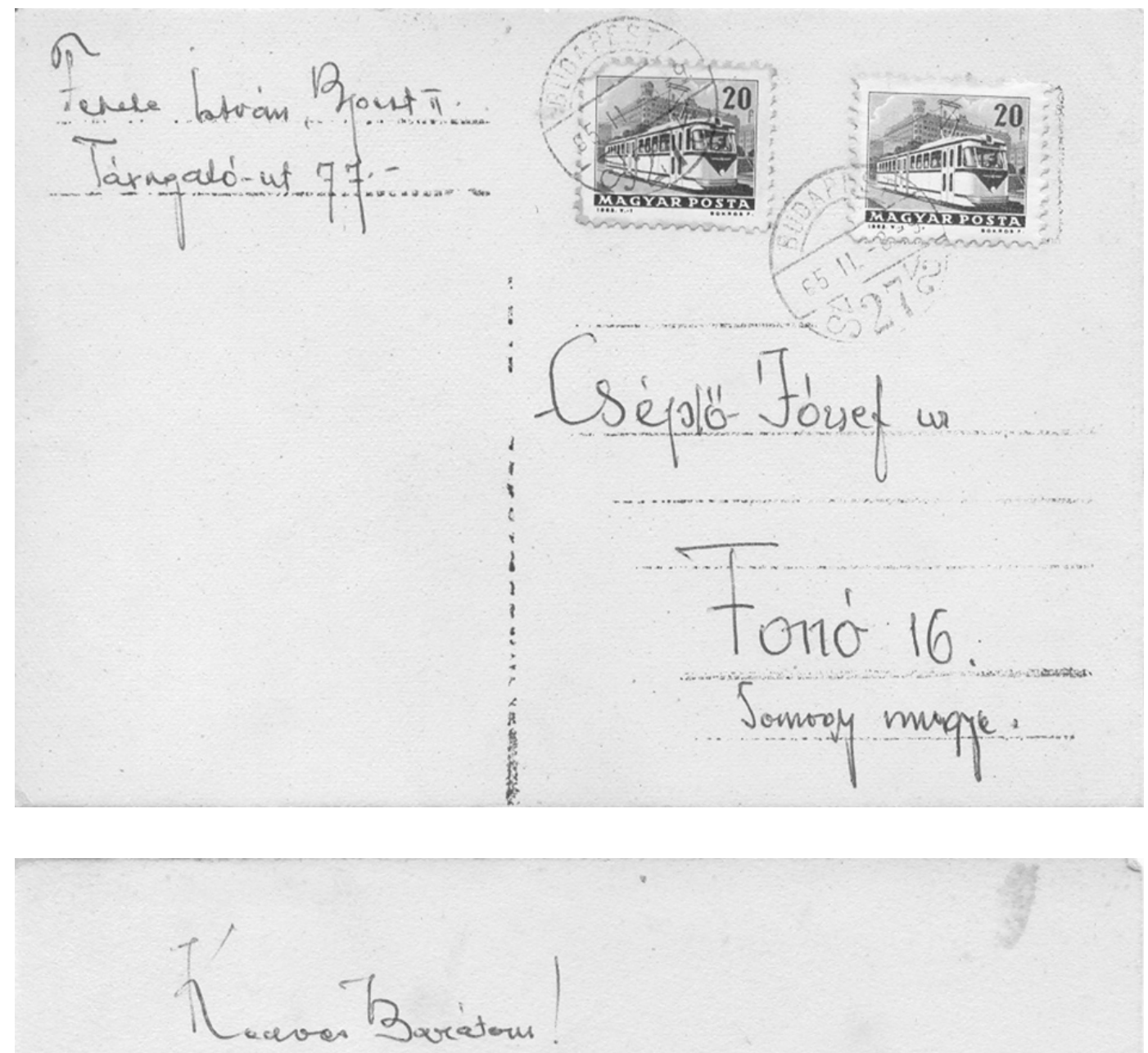

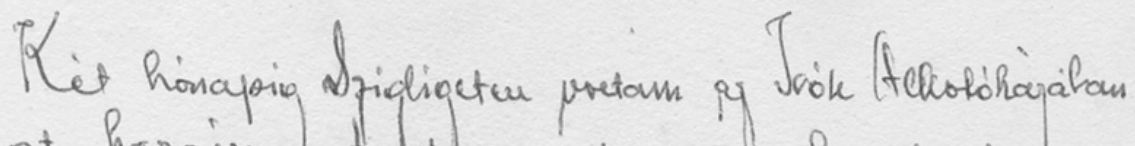
is unost haraiesvel tubetam esah moo, hror karaiadny

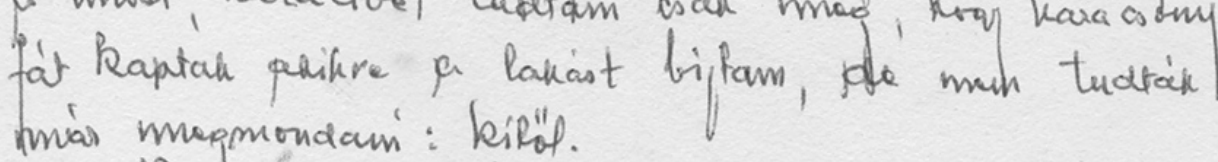

Difos pagyoh benne, how Te baildted, hat bocians

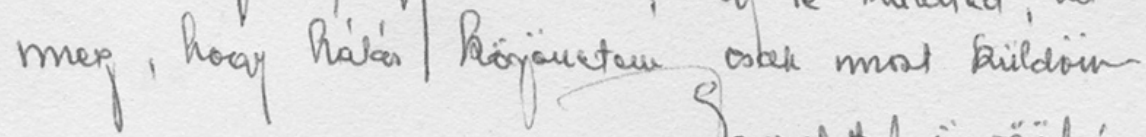

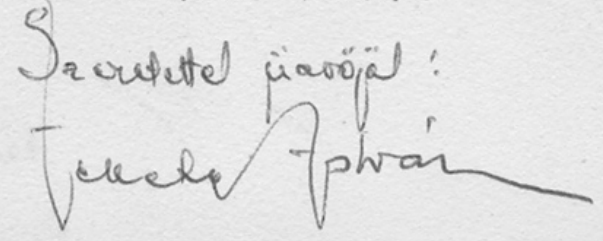



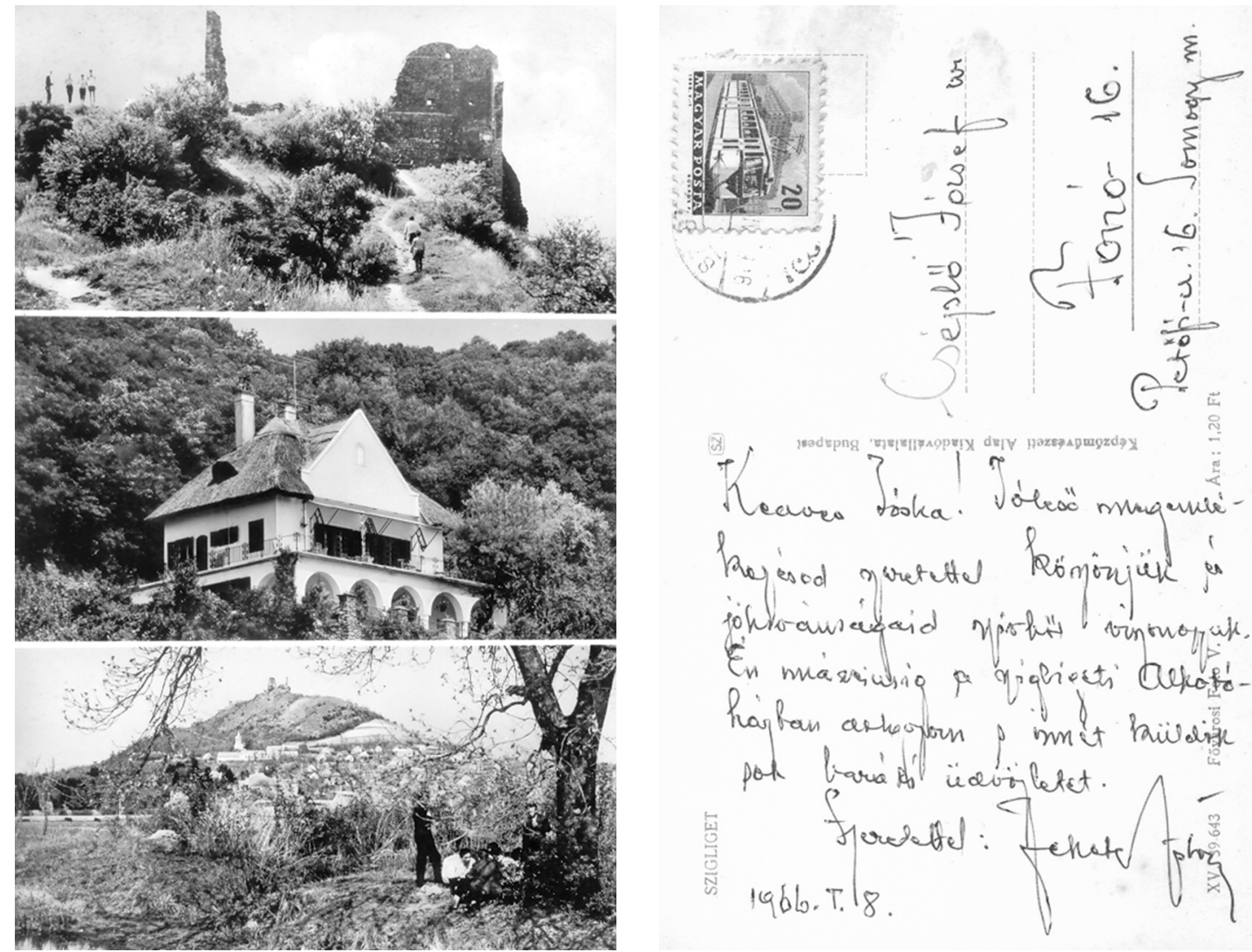

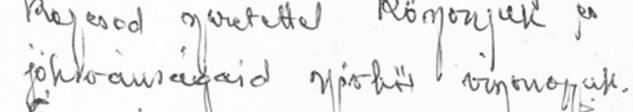

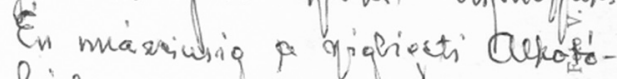

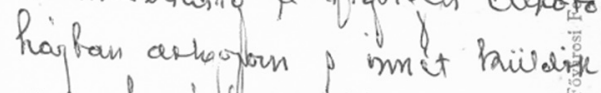

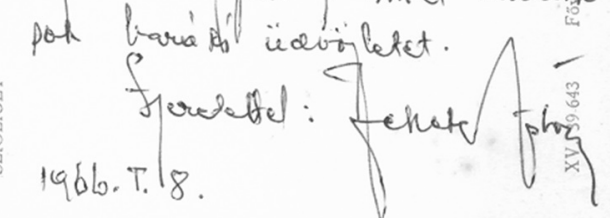

13. levél. Fekete István levele Cséplő Józsefnek (1966. I. 8.)
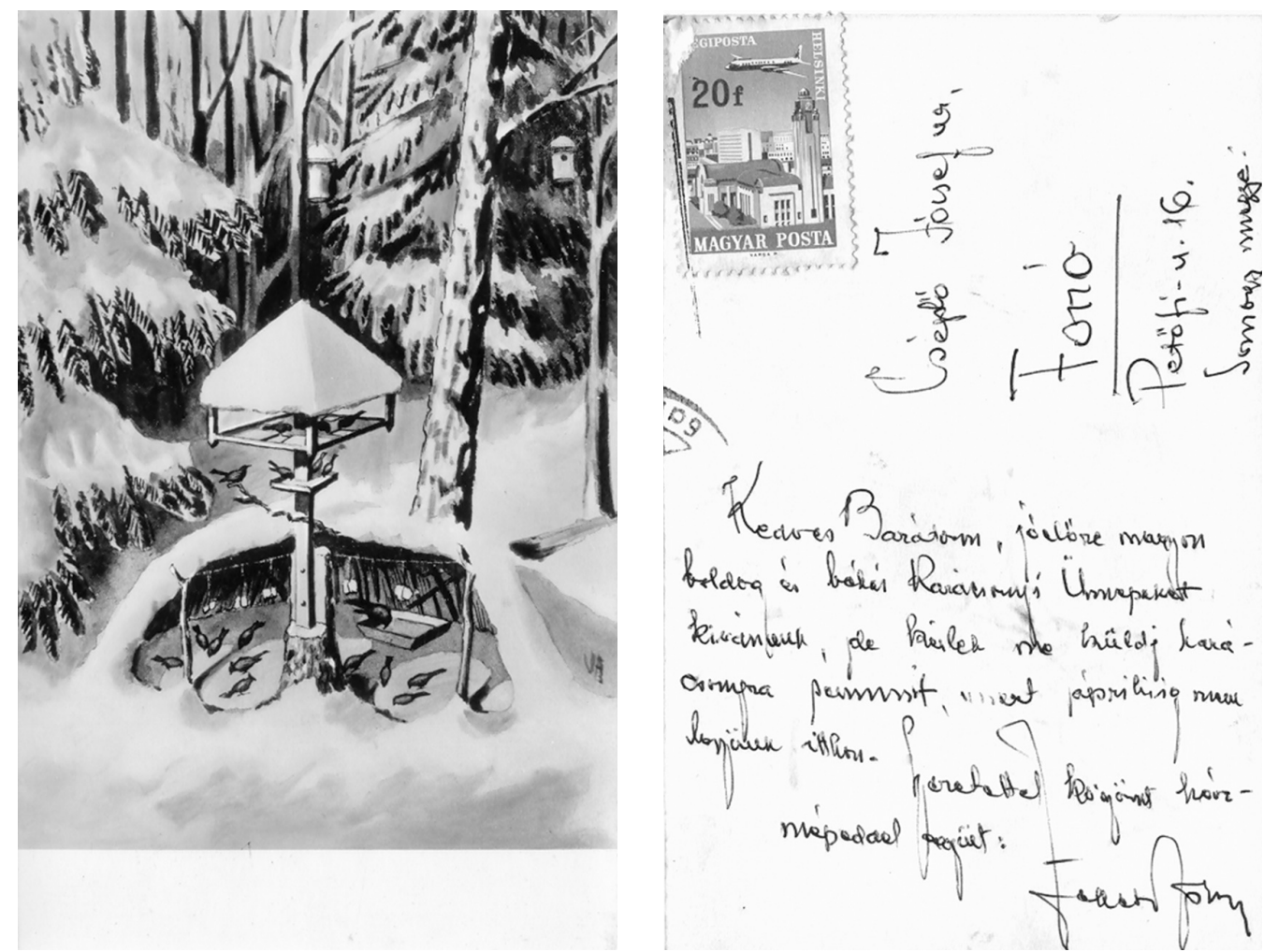

14. levél. Fekete István levele Cséplő Józsefnek 

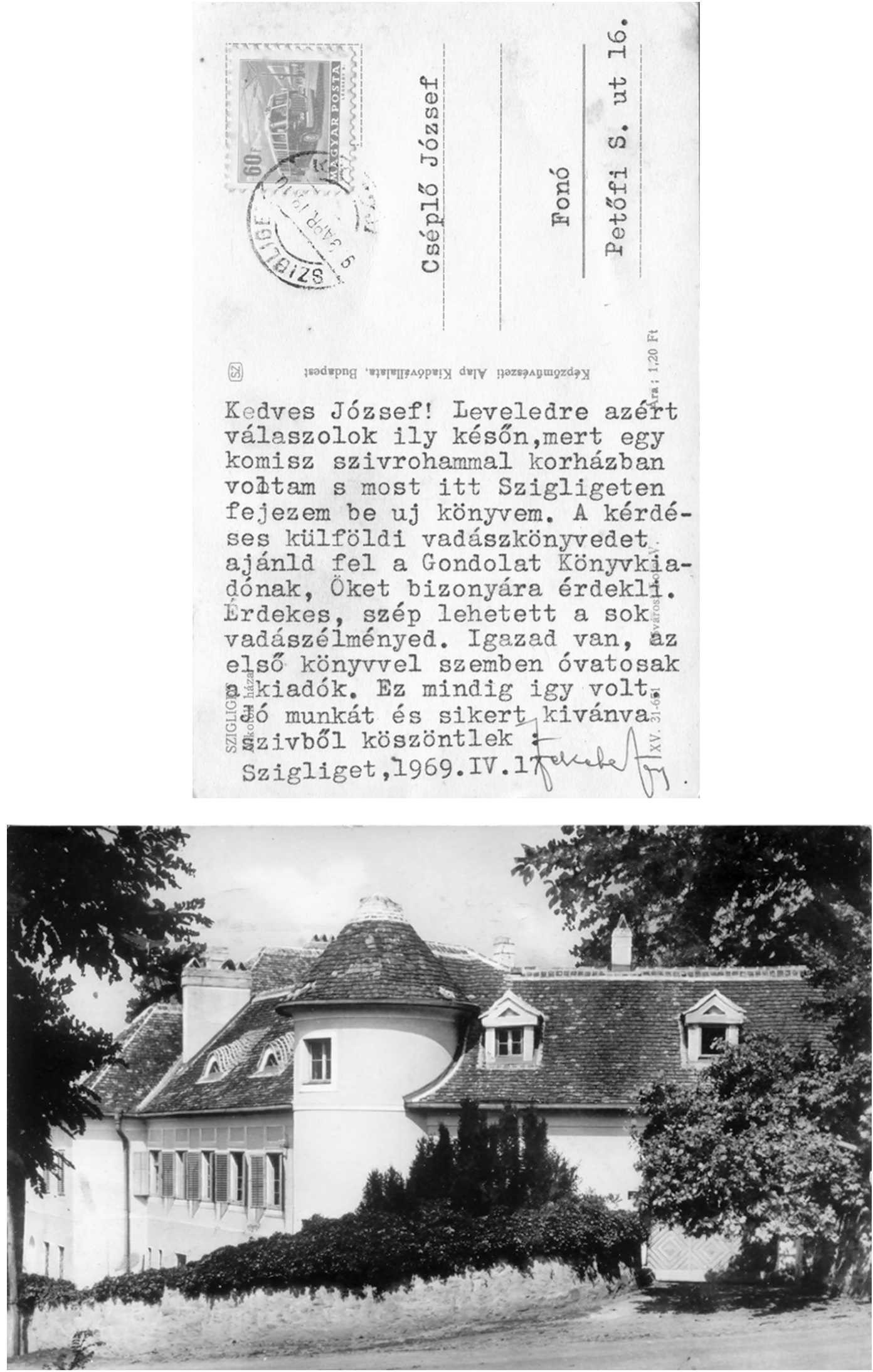

15. levél. Fekete István levele Cséplő Józsefnek (1969. IV. 17.) 


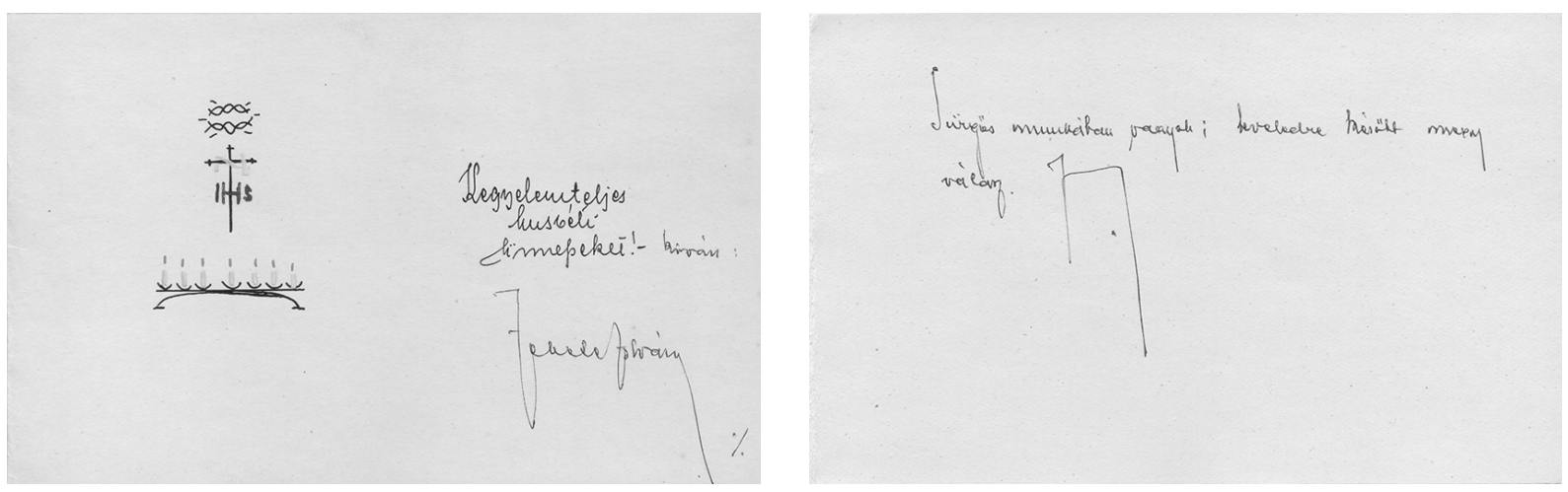

16 levél. Fekete István levele Cséplő Józsefnek

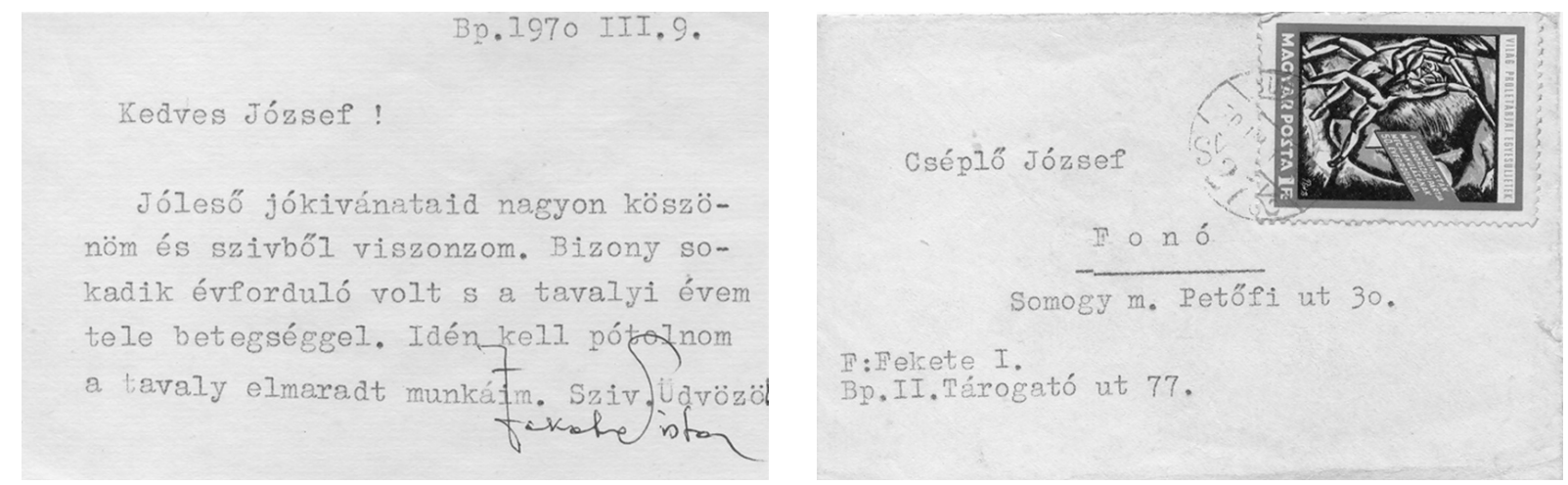

17. levél. Fekete István levele Cséplő Józsefnek (1970. március. 9.)
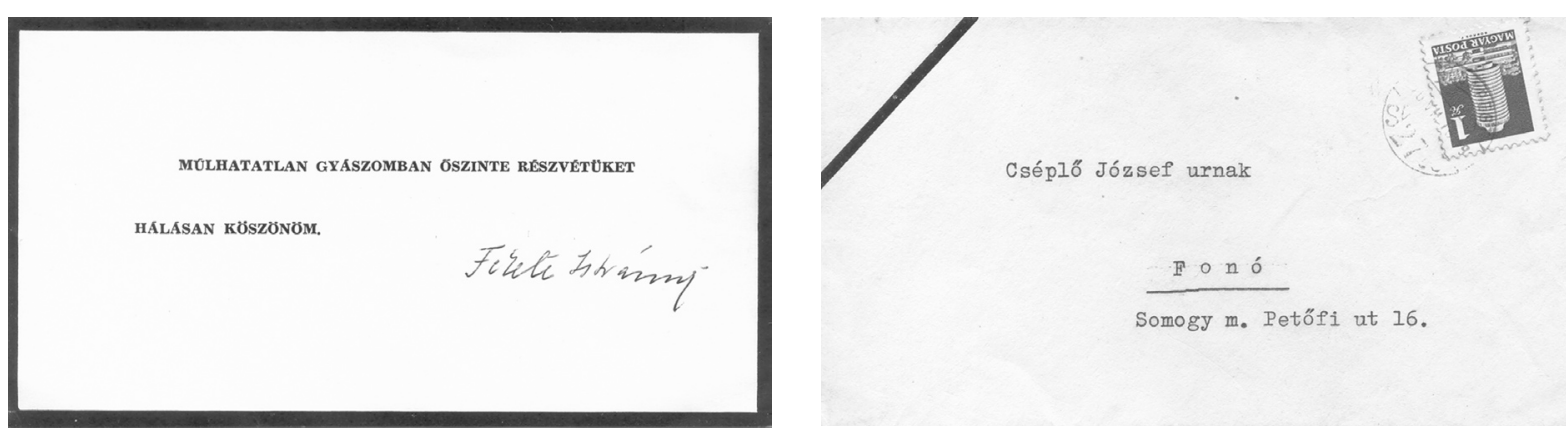

18. levél. Az utolsó levél a Tárogató utcából

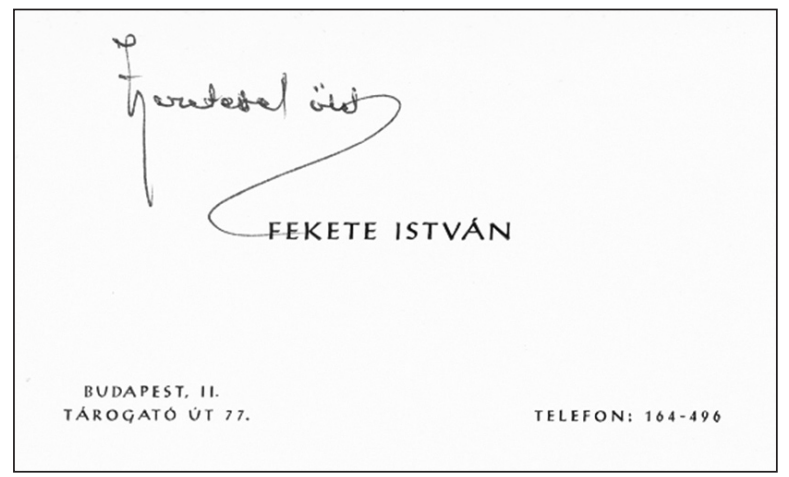

19. levél. Fekete István névjegykártyája, személyes megjegyzéssel Cséplő Józsefnek 